\title{
Chemistry of 3-carbonyl-2-methyl-4-oxo-4H-1-benzopyrans
}

\author{
Chandra Kanta Ghosh*a and Amarnath Chakraborty \\ ${ }^{a}$ Organic Chemistry Laboratory, Department of Biochemistry, Calcutta University \\ Kolkata 700 019, India \\ ${ }^{b}$ Department of Basic Sciences and Humanities, Institute of Engineering \& Management \\ Salt Lake Electronics Complex, Sector-5, Kolkata 700 091, India \\ Email: ghosh.chandrakanta@gmail.com
}

DOI: $\underline{\text { http://dx.doi.org/10.3998/ark.5550190.p009.449 }}$

\begin{abstract}
The review article gives a comprehensive survey of the synthesis and chemistry of the title benzopyrans covering the literature published during 1980 - August 2015.

Keywords: Chromones, acylation, Michael addition, [6+0]cyclization, radical cyclization, metal complex formation
\end{abstract}

\section{Table of Contents}

1. Introduction

2. Synthesis

2.1 Synthesis of 3-formyl-2-methylchromone $\mathbf{1}$

2.2 Synthesis of 3-acetyl-2-methylchromone 2

2.3 Synthesis of 3-benzoyl-2-methylchromone $\mathbf{3}$

2.4 Synthesis of 3-hydroxycarbonyl- and 3-alkoxycarbonyl-2-methylchromone 4 and 5

3. Conjugate Addition to the Pyran 2,3-Olefinic Bond of Chromones without Pyran Ring Opening

3.1 Conjugate reduction

3.2 Conjugate addition of alkyl and alkoxy groups

4. Conjugate Addition with Other Concomitant Reactions

4.1 Addition of ammonia and amines

4.2 Addition of nitrogenous dinucleophiles

4.2.1 Dinucleophiles having adjacent nucleophilic centres

4.2.2 Dinucleophiles with two nucleophilic centres separated by one carbon

4.2.3 Dinucleophiles with two nucleophilic centres separated by two carbons 


\subsection{Addition of carbon nucleophiles}

5. Bromination of 3-Acyl-2-methylchromones $\mathbf{2}$ and $\mathbf{3}$, and Reactions of the Resultant Bromo Derivatives

6. Benzopyrans 1-5 as Nucleophiles

6.1 Addition to carbonyl compounds

6.2 Addition to unsaturated carbonyl compounds

7. Aminomethylenation of 2-Methylchromones 1-5: Reactions of 2-(2-Dimethylaminoethenyl)chromones

8. 3-Acetyl-2-methylchromone as a Ligand in Mixed Ligand Metal Complexes

9. Conclusion

References

\section{Introduction}

2-Methyl-1-benzopyran-4-ones 1-5 belong to the chromone family, and, like their respective 2unsubstituted homologues $\mathbf{6}$, possess an activated endocyclic olefinic bond, three electrophilic centres, namely pyran $\mathrm{C}-2$, exocyclic carbonyl carbon and an endocyclic carbonyl carbon. In chromone 6, C-2 is much more electrophilic than the exocyclic carbonyl carbon, and C-4 is the least electrophilic position. Electrophilicity at the methyl substituted C-2 of chromones 1-5 is evidently less than that at C-2 of their lower homologues $\mathbf{6}$ due to the positive inductive effect and hyperconjugation of the methyl group. The 2-methyl group in 1-5, being vinylogous to two carbonyl groups, is more acidic than that in 2-methylchromone $\mathbf{8}$, and functions as a nucleophile in the presence of an appropriate base. Because of these functionalities (activated olefinic bond, electrophilicity at three centres and nucleophilicity at the 2-methyl group), the chemistry of 2methylchromones 1-5 is more varied than that of the lower homologues 6. Of the several review articles on chromones, the latest one on 2-methylchromone $\mathbf{8}^{1}$, two on the nitrile $\mathbf{7 \mathbf { a } ^ { 2 , 3 }}$ and three on 3-formylchromone $\mathbf{6} \mathbf{a}^{4-6}$ are noteworthy. In contrast, a full, complete and up-to-date survey on the chemistry of the title chromones $\mathbf{1 - 5}$ is still lacking.

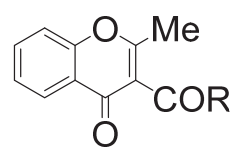

1: $\mathrm{R}=\mathrm{H}$

2: $\mathrm{R}=\mathrm{Me}$

3: $\mathrm{R}=\mathrm{Ph}$

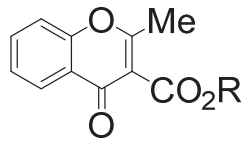

4: $\mathrm{R}=\mathrm{H}$

5a: $\mathrm{R}=\mathrm{Me}$

5b: $R=E t$

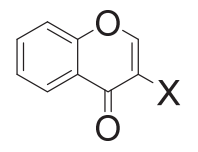

6a: $\mathrm{X}=\mathrm{CHO}$

6b: $X=\mathrm{COMe}$

6c: $X=\mathrm{COPh}$

6d: $X=\mathrm{CO}_{2} \mathrm{H}$

6e: $\mathrm{X}=\mathrm{CO}_{2} \mathrm{Me}$ or $\mathrm{CO}_{2} \mathrm{Et}$

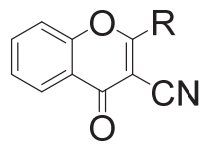

7

7a: $\mathrm{R}=\mathrm{H}$

7b: $\mathrm{R}=\mathrm{Me}$

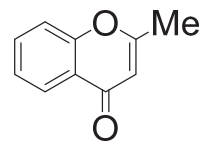

8

Research in the chemistry of the title topic started in 1921 with the synthesis of 3-acetyl-2methylbenzo[f]chromone by treatment of 2-methoxynaphthalene with acetic anhydride and 
sulfoacetic acid. Here the methoxy group of the initially formed 1-acetyl-2-methoxynaphthalene probably undergoes hydrolysis under the reaction conditions and the resultant intermediate by further acetylation and cyclization gives the final product. ${ }^{7}$ Over the following six decades research has mainly revolved around the synthesis of 3-acylchromones $\mathbf{2}$ and $\mathbf{3}$ and their reactions with simple nitrogen nucleophiles. The present article is a comprehensive survey of the chemistry and applications of the chromones 1-5, and covers the literature published during the period 1980 to August 2015. Patented works on the chromones 1-5 are excluded, and the biological activity of compounds 1-5 and the products obtainable therefrom are less emphasized. Most of the reactions described here for the chromones 1-5 generally do not affect any alkyl, alkoxy and halogeno substituents if present in the benzene ring, or on aromatic or heterocyclic rings if fused with the benzene ring of these chromones.

\section{Synthesis}

The easily available $o$-hydroxyacetophenone can serve as a synthon for the title chromones 1-5.

\subsection{Synthesis of 3-formyl-2-methylchromone 1}

The chromone $\mathbf{1}$ is conveniently prepared by treating the enaminoketone, derived from $o$ hydroxyacetophenone and $N, N$-dimethylformamide dimethyl acetal, with acetic anhydride. This method has been adopted for the preparation of 3-formyl-2-methylbenzo[ $h]$ chromone 11 from 2acetyl-1-naphthol 9 (Scheme 1). ${ }^{8}$ It is worth mentioning here that the enaminoketone 10 gives the chromone derivatives 12, 13 and 14 by treatment with $\mathrm{AcOH}, \mathrm{SOCl}_{2}$ and $\mathrm{Br}_{2}$, respectively. ${ }^{8}$

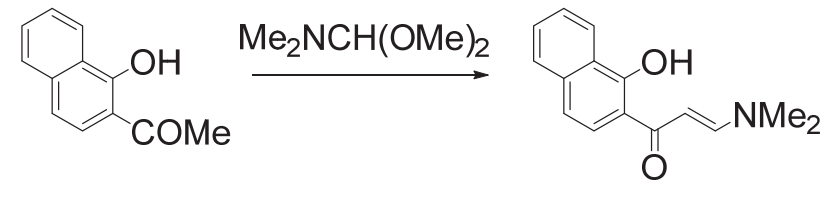

9

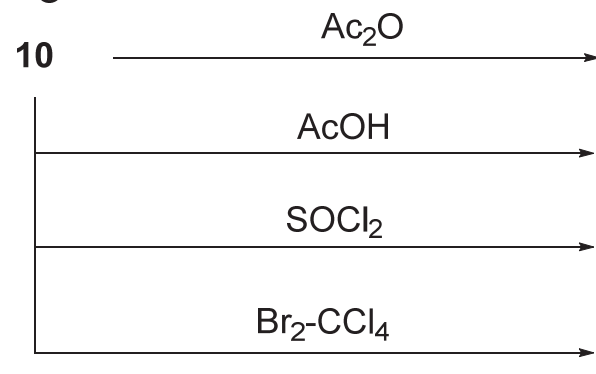

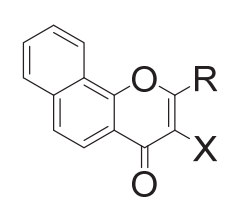

11: $\mathrm{R}=\mathrm{Me}, \mathrm{X}=\mathrm{CHO}$

12: $R=X=H$

13: $\mathrm{R}=\mathrm{H}, \mathrm{X}=\mathrm{SO}_{2} \mathrm{H}$

14: $R=X=B r$

\section{Scheme 1}

Benzofuran derivatives 15a,b have similarly been converted into 6-formylvisnagin 16a and 6-formylkhellin $\mathbf{1 6 b}$, respectively. ${ }^{9}$ 


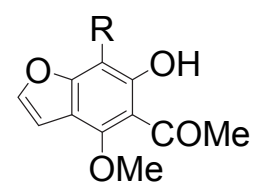

15

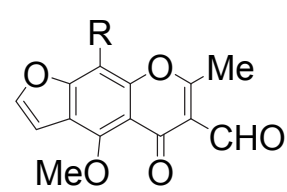

16

For 15 and 16

a : $\mathrm{R}=\mathrm{H}$

b : $\mathrm{R}=\mathrm{OMe}$

The aldehyde 1 has also been prepared from preformed 2-methyl-, 3-formyl- and 3acetyl-chromone (8, 6a and $\mathbf{6 b})$. 2-Methylchromone $\mathbf{8}$ is chloromethylated by paraformaldehydehydrogen chloride to 17 which is converted into 19 via $\mathbf{1 8}$; pyridinium dichromate oxidizes the alcohol 19 to the aldehyde $\mathbf{1}$ (Scheme 2). ${ }^{10}$

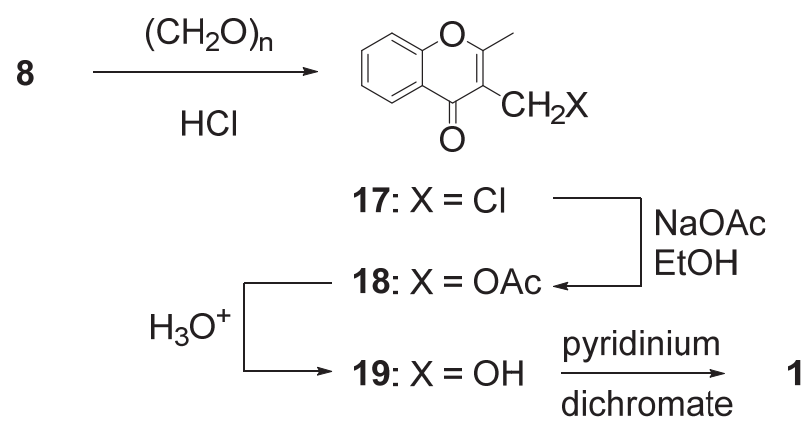

\section{Scheme 2}

Lithium dimethylcuprate causes conjugate addition of the methyl group to chromone-3carbaldehyde 6a, and the resultant 3-formyl-2-methylchromanone can be dehydrogenated by trityl tetrafluoroborate $\left[\mathrm{Ph}_{3} \mathrm{C}\right]\left[\mathrm{BF}_{4}\right]$ to the aldehyde 1 in $56 \%$ yield. ${ }^{11}$ Treatment of the dioxolane $\mathbf{2 0}$, derived from 6a and ethylene glycol, with diazomethane gives the 1-pyrazoline $\mathbf{2 2}$ that gives exclusively 2-methylchromone $\mathbf{2 1}$ when heated under reflux in toluene but $\mathbf{2 1}$ admixed with a small amount of the aroylpyrazole $\mathbf{2 3}$ when heated neat. The compound $\mathbf{2 1}$ on treatment with aqueous acid gives 3-formyl-2-methylchromone $\mathbf{1}$ (Scheme 3 ). ${ }^{12,13}$

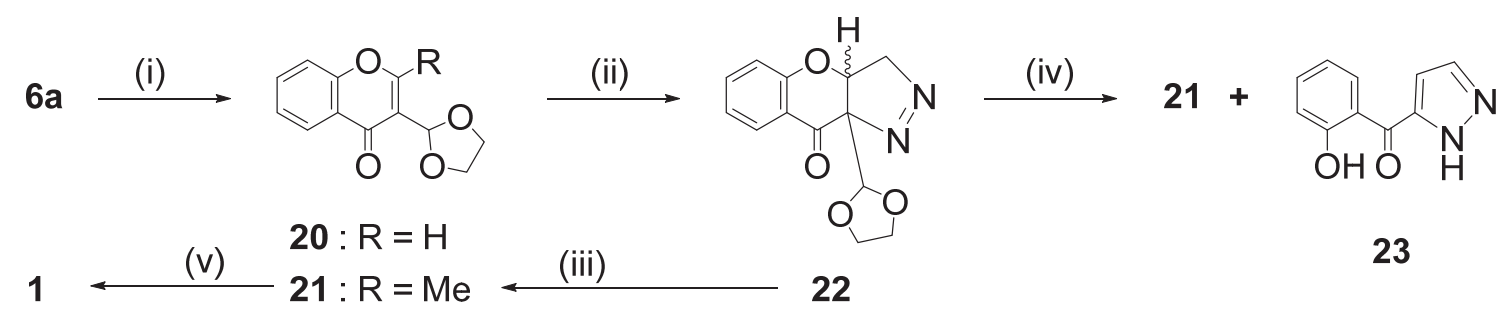

Scheme 3. Reagents and conditions: (i) $\mathrm{HOCH}_{2} \mathrm{CH}_{2} \mathrm{OH}, \mathrm{PhH}, \mathrm{PTSA}, \Delta$; (ii) $\mathrm{CH}_{2} \mathrm{~N}_{2}, \mathrm{CH}_{2} \mathrm{Cl}_{2}$; (iii) $\mathrm{PhMe}, \Delta$; (iv) $\Delta$; (v) $\mathrm{H}_{2} \mathrm{O}, \mathrm{H}^{+}$, warm. 
Another method for the preparation of the aldehyde $\mathbf{1}$ involves acid hydrolysis of the hydrazone 24 arising through an aza-Michael addition of 1,1-dimethylhydrazine to the $\alpha, \beta$ unsaturated ketone functionality of $\mathbf{6 b}$ with concomitant opening of the pyran ring and recyclization (Scheme 4). ${ }^{14}$

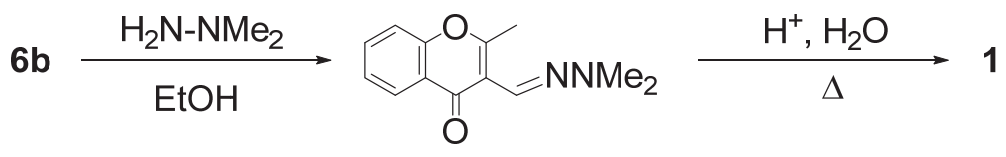

\section{Scheme 4}

\subsection{Synthesis of 3-acetyl-2-methylchromone 2}

Synthesis of 3-acylchromones $\mathbf{2}$ and $\mathbf{3}$ from $o$-hydroxyacetophenone $\mathbf{2 5}$ involves a three-step process namely (i) $\mathrm{O}$-acylation of $\mathbf{2 5}$ with acyl chloride $\mathrm{RCOCl}$ or acid anhydride ( $\mathrm{RCO})_{2} \mathrm{O}$ to 26, (ii) Baker-Venkataraman rearrangement of $\mathbf{2 6}$ to 27 and (iii) treatment of 27 with acetic anhydride, the final step involving the formation of the non-isolable intermediate $\mathbf{2 8}$ which spontaneously cyclizes to $\mathbf{2}$ or $\mathbf{3}$ (Scheme 5).

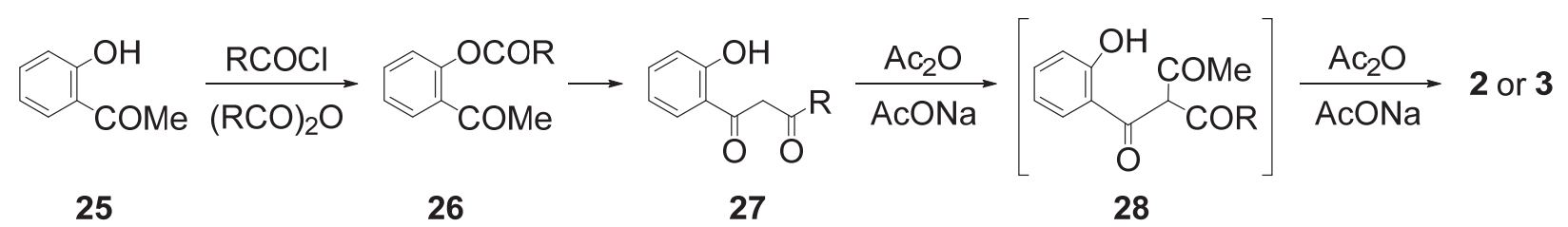

For 26-28: $\mathrm{R}=\mathrm{Me}$ or $\mathrm{Ph}$

\section{Scheme 5}

Kostanecki-Robinson synthesis of $\mathbf{2}$ by just heating 25 with $\mathrm{Ac}_{2} \mathrm{O}-\mathrm{AcONa}$ involves all the above three steps. 3-Acetyl-2-methylchromone $\mathbf{2}$ and its variously substituted analogues have been synthesized by the Kostanecki-Robinson method. Ganguly et al. ${ }^{15}$ have used $\mathrm{MeCOCl}$ in DBU-pyridine, instead of $\mathrm{Ac}_{2} \mathrm{O}$-AcONa, for preparing some 5- or 7-mono and 5,7-disubstituted analogues of $\mathbf{2}$ from the corresponding $o$-hydroxyacetophenones.

Resacetophenone (29a) on treatment with arylmethanol $\mathrm{ArCH}_{2} \mathrm{OH}\left(\mathrm{Ar}=\mathrm{Ph}, 4-\mathrm{MeOC}_{6} \mathrm{H}_{4}\right)$ in the presence of $\mathrm{BF}_{3}$-ether gives the mono- and di-benzylated acetophenone 30a-c. ${ }^{16,17}$ Similar treatment of 29a and phloracetophenone (29b) with $\mathrm{Ph}_{2} \mathrm{CHOH}$ gives $\mathbf{3 0 d - \mathbf { f } ^ { 1 8 }}$ and 31a-c, ${ }^{19}$ respectively. All these substituted acetophenones $\mathbf{3 0}$ and $\mathbf{3 1}$ have been heated with $\mathrm{Ac}_{2} \mathrm{O}-\mathrm{AcONa}$ to yield the corresponding 3-acetyl-2-methylchromones. 2-Acetyl-1-hydroxycarbazole $32\left(\mathrm{R}^{1}\right.$, $\mathrm{R}^{2}, \mathrm{R}^{3}=\mathrm{H}, \mathrm{Me}$ ) obtained along with 2,4-diacetyl-1-hydroxycarbazole by acylation of 1hydroxycarbazole with $\mathrm{AcCl}$ in the presence of anhydrous $\mathrm{AlCl}_{3}$ and $\mathrm{POCl}_{3}$ has been subjected 
to Kostanecki-Robinson reaction to give the corresponding chromone. ${ }^{20}$ With $\mathrm{Ac}_{2} \mathrm{O}-\mathrm{AcONa}$, the benzopyran $\mathbf{3 3}$ gives $\mathbf{3 5},^{21}$ and $\mathbf{3 4}$ a mixture of $\mathbf{3 6}$ and $\mathbf{3 7} .^{22}$<smiles>[R]c1cc(O)cc(O)c1C(C)=O</smiles>

29a: $\mathrm{R}=\mathrm{H}$,

b: $\mathrm{R}=\mathrm{OH}$<smiles>[R]c1cc(C(C)=O)c(O)c([R])c1O</smiles>

30a: $R^{1}=H, R^{2}=\mathrm{CH}_{2} \mathrm{Ar}$

b: $\mathrm{R}^{1}=\mathrm{CH}_{2} \mathrm{Ar}, \mathrm{R}^{2}=\mathrm{H}$

c: $R^{1}=R^{2}=C_{2} \mathrm{Ar}$

d: $\mathrm{R}^{1}=\mathrm{Ph}_{2} \mathrm{CH}, \mathrm{R}^{2}=\mathrm{H}$

e: $\mathrm{R}^{1}=\mathrm{H}, \mathrm{R}^{2}=\mathrm{Ph}_{2} \mathrm{CH}$

f: $\mathrm{R}^{1}=\mathrm{R}^{2}=\mathrm{CHPh}_{2}$

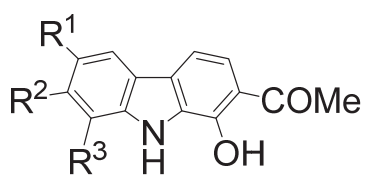

32<smiles>[R]c1c2c(cc(O)c1C(C)=O)OC(C)(C)CC2</smiles>

33: $\mathrm{R}=\mathrm{H}$

34: $\mathrm{R}=\mathrm{OH}$<smiles>[R]c1c(O)c([R])c(O)c(C(C)=O)c1O</smiles>

31a: $\mathrm{R}^{1}=\mathrm{Ph}_{2} \mathrm{CH}, \mathrm{R}^{2}=\mathrm{H}$

b: $\mathrm{R}^{1}=\mathrm{H}, \mathrm{R}^{2}=\mathrm{Ph}_{2} \mathrm{CH}$

c: $\mathrm{R}^{1}=\mathrm{R}^{2}=\mathrm{CHPh}_{2}$

Ghate and $\mathrm{Kulkarni}^{23}$ prepared the furo[3,2-g]benzopyran 41 containing a coumarin moiety at its 2-position by $\mathrm{Ac}_{2} \mathrm{O}-\mathrm{AcONa}$ treatment of 40, derived from coumarin $\mathbf{3 8}$ and diacetylresorcinol 39 (Scheme 6) and assessed its anti-inflammatory and analgesic activity.

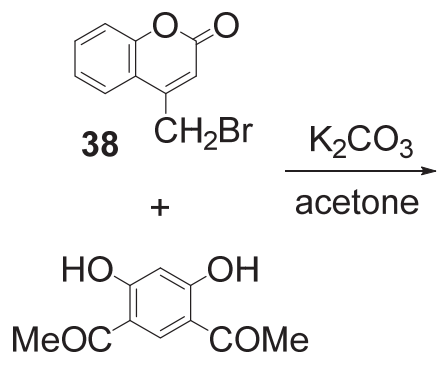

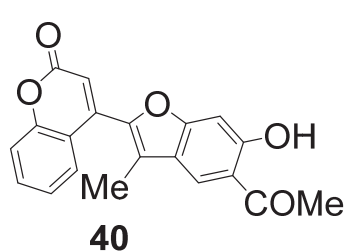

35: $\mathrm{R}=\mathrm{H}$

36: $\mathrm{R}=\mathrm{OH}$

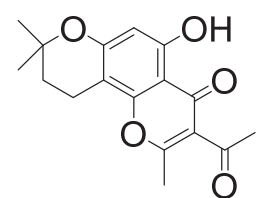

37

39

\section{Scheme 6}

Conversion of the acetophenone 42 to 2-acetylchromone 43 by treatment with either $\mathrm{Ac}_{2} \mathrm{O}-\mathrm{AcONa}$ as stated in the chemistry as well as experimental section or $\mathrm{AcOH}-\mathrm{AcONa}$ as (perhaps erroneously) printed in the reaction scheme of a publication ${ }^{24}$ is unlikely; the substrate 42 in $\mathrm{Ac}_{2} \mathrm{O}$-AcONa under reflux evidently affords the chromone 44 (Scheme 7). 


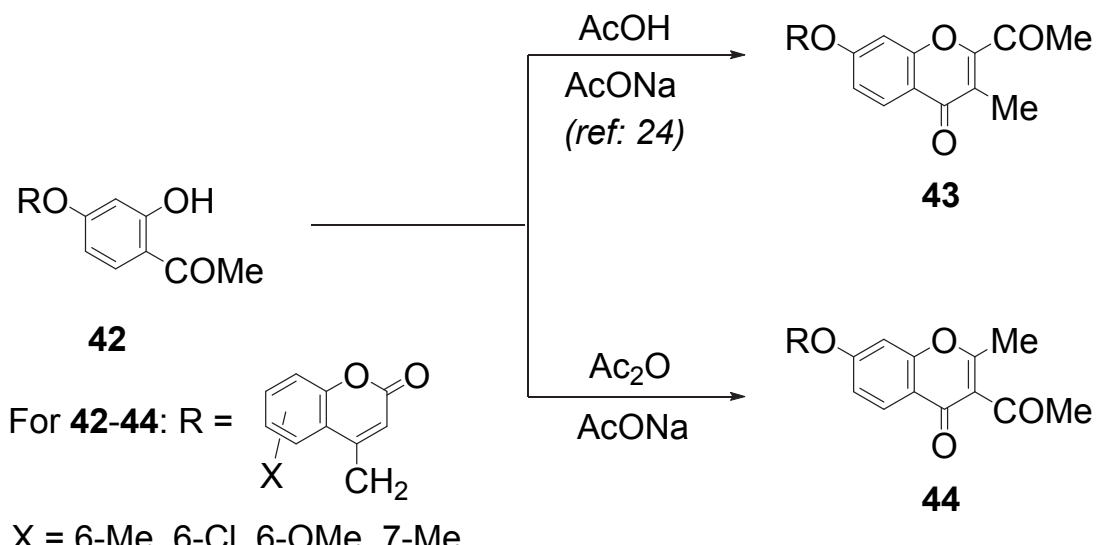

\section{Scheme 7}

Treatment of the diacetoxyacetophenone $\mathbf{4 5}$ with sodamide results in cyclization and an intermolecular acetyl group transfer to give $\mathbf{4 6}$ admixed with $\mathbf{4 7}$, the deacylated product from $\mathbf{4 5}$ (Equation 1). ${ }^{25}$

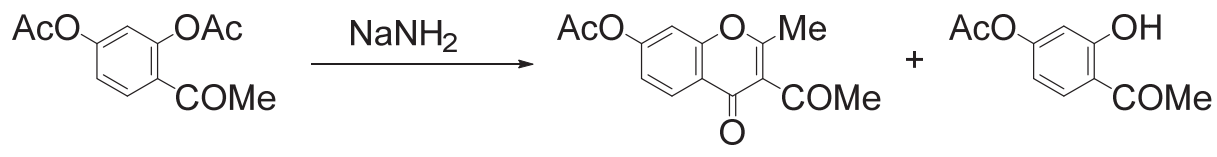

45

46

47

$\mathrm{TiCl}_{4}$-catalyzed Friedel-Crafts acylation of some substituted phenols with either $\mathrm{AcCl}^{26}$ or $\mathrm{AcOH}^{27}$ is often followed by Allan-Robinson reaction to some extent so as to form 3-acetyl-2methylchromones (Equations 2 and 3).

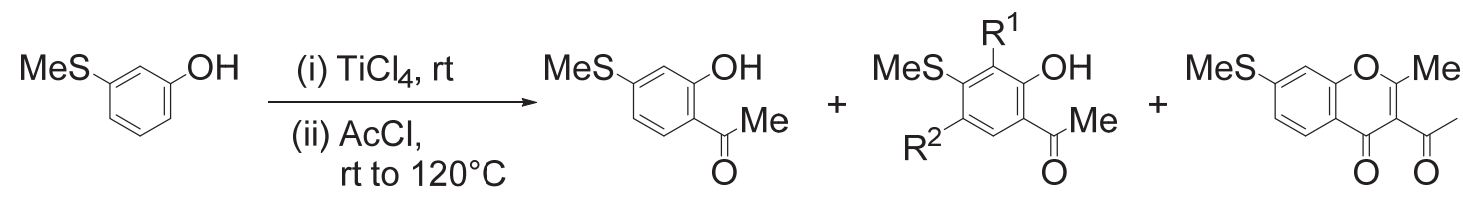

48

49

50a: $R^{1}=A c, R^{2}=H$

51

b: $R^{1}=R^{2}=A c$

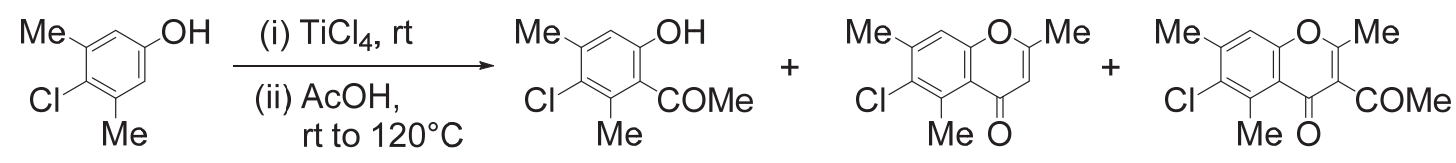

52

$53(60 \%)$

$54(6 \%)$

$55(30 \%)$

Iron(III) exchanged sepiolites (Fe-Sp) operate as Lewis acids in thermolysis of the styrene 56 under reduced pressure to $2^{\prime}$-acetoxyacetophenone $\mathbf{5 7}$ and chromones $\mathbf{2}$ and $\mathbf{8}$ (Equation 4). ${ }^{28}$<smiles>C=C(C)Oc1ccccc1OC(C)=O</smiles>

56

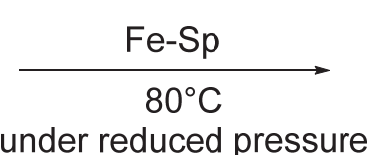

under reduced pressure

$57(8 \%)$<smiles>COc1c(C(=O)c2ccccc2)oc2ccccc2c1=O</smiles>

$2(2 \%)$<smiles>Cc1cc(=O)c2ccccc2o1</smiles>

$8(10 \%)$ 
Acetylation at the 3-position of 2-methylchromone $\mathbf{8}$ is also known. As for example, equimolar amounts of $\mathbf{8}$ and $\mathrm{Ac}_{2} \mathrm{O}$ over a HBEA zeolite $(\mathrm{Si} / \mathrm{Al}=10)$ in a batch reactor or a fixed bed reactor at $60^{\circ} \mathrm{C}$ gives chromone $2 .{ }^{29}$ Acetylation of visnagin $\mathbf{5 8 a}$ and khellin $\mathbf{5 8 b}$ by $\mathrm{Ac}_{2} \mathrm{O}$ $\mathrm{Zn}$ dust to the respective 6-acetyl derivative 59a and 59b has also been achieved. ${ }^{30}$ Diazomethane at $-70{ }^{\circ} \mathrm{C}$ effects dual alkylation of 3-formyl-6-methylchromone yielding 3 -acetyl-2,6-dimethylchromone, ${ }^{31}$ but in ice-cold ether or dichloromethane solution it converts 3-formylchromone $\mathbf{6 a}$ into 3 -acetyl-2-methylchromone $\mathbf{2}$ in only $2 \%$ yield together with furo$[3,4-b][1]$ benzopyran 59' $(16 \%)$ and [1]benzopyrano[3,2-c]pyrazole 59" $(2 \%) .^{32}$

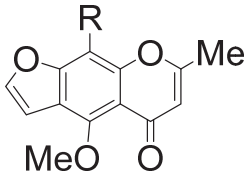

58a: $\mathrm{R}=\mathrm{H}$

b: $\mathrm{R}=\mathrm{OMe}$

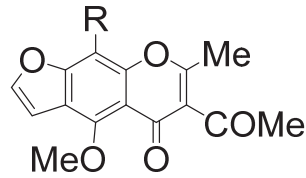

59a: $\mathrm{R}=\mathrm{H}$

b: $\mathrm{R}=\mathrm{OMe}$

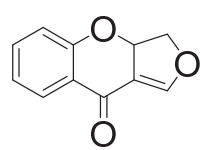

59'

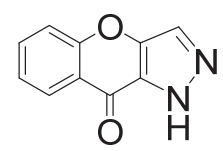

$59 "$

Deacetylation of several 3-acetyl-2-methylchromones by treatment with aqueous sodium carbonate is resorted to for preparation of otherwise difficultly accessible 2-methylchromones. For example, 5,7-dihydroxy-2-methylchromone 61, needed for the synthesis of schumanniophytine and isoschumanniophytine, has been prepared by $\mathrm{Na}_{2} \mathrm{CO}_{3}-\mathrm{H}_{2} \mathrm{O}$ treatment of the 3acetylchromone 60, obtainable from phloracetophenone $\mathbf{2 9 b}$ and $\mathrm{Ac}_{2} \mathrm{O}-\mathrm{AcONa}^{33}$ The chromone 62b obtained by similar deacetylation of 3-acetylchromone 62a is treated with $\mathrm{I}_{2}-\mathrm{CF}_{3} \mathrm{CO}_{2} \mathrm{Ag}$ to afford 3-iodochromone 62c; the latter (62c) on Suzuki coupling with arylboronic acid leads to 3aryl-2-methylchromones 62d $\left(\mathrm{Ar}=\mathrm{Ph}, 4-\mathrm{ClC}_{6} \mathrm{H}_{4}, 4-\mathrm{MeOC}_{6} \mathrm{H}_{4}, 2\right.$-naphthyl, $\mathrm{C}_{6} \mathrm{H}_{4} \mathrm{Ph}$ etc. $){ }^{34}$

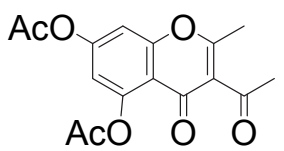

60

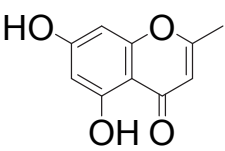

61

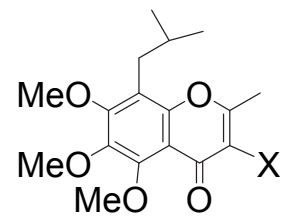

62a: $X=\mathrm{COMe}$

b: $X=\mathrm{H}$

c: $X=1$

d: $X=A r$

\subsection{Synthesis of 3-benzoyl-2-methylchromone (3)}

A general method for the synthesis of chromone $\mathbf{3}$ starting from $o$-hydroxyacetophenone via $\mathbf{2 6}$ and $27(\mathrm{R}=\mathrm{Ph})$ is shown in Scheme 5. Unsubstituted and various substituted 2'-hydroxyacetophenones, ${ }^{35-37}$ 3,6-diacetyl-5-hydroxyindole ${ }^{38}$ and benzofuran $\mathbf{1 5} \mathbf{b}^{39}$ have been converted into the corresponding 3-benzoylchromones. $\mathrm{Ac}_{2} \mathrm{O}-\mathrm{DMSO}^{40}$ and $\mathrm{Ac}_{2} \mathrm{O}$ in DMAP/pyridine, ${ }^{41}$ instead of $\mathrm{Ac}_{2} \mathrm{O}-\mathrm{AcONa}$, have also been used for the conversion of many 2'-hydroxy- $\omega$-benzoylacetophenones to chromones analogous to 3 . 
3-Benzoyl-2-methylchromone $\mathbf{3}$ has also been prepared from 2-methylchromone $\mathbf{8}$ as well as 3-benzoylchromone 6c. Lithium diisopropylamide (LDA, from diisopropylamine and butyl lithium) can cause vinylic deprotonation and classical deprotonation of the active methylene group. Costa et al. ${ }^{42}$ prepared 3-benzoyl-2,6-dimethylchromone 64 in $46 \%$ yield by sudden addition of ethyl benzoate to a LDA solution in hexane kept at $-78^{\circ} \mathrm{C}$ followed immediately by the addition of 2,6-dimethylchromone $\mathbf{6 3}$ and quenching the reaction after $3 \mathrm{~h}$ with $\mathrm{AcOH}-\mathrm{H}_{2} \mathrm{O}$ (Equation 5). This is an example wherein vinylic deprotonation predominates over deprotonation of a sufficiently active 2-methyl group of chromone 63. The chromone 3 along with three other products is obtained by treating 3-benzoylchromone $6 \mathbf{c}$ with diazomethane. ${ }^{32}$

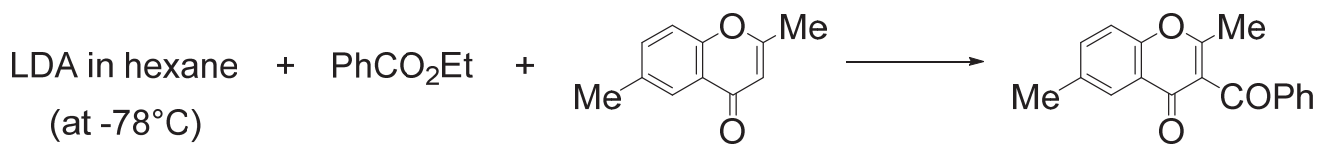

63

\subsection{Synthesis of 3-hydroxycarbonyl- and 3-alkoxycarbonyl-2-methylchromone 4 and 5}

2-Hydroxy- and 2-fluoro-benzoic acid chlorides are synthons for the acid $\mathbf{4}$ and ester $\mathbf{5}$. Ethyl acetoacetate in the presence of $40 \% \mathrm{NaOH}^{43}$ as well as its morpholino-enamine ${ }^{44}$ gives with salicyloyl chloride the ester $\mathbf{5 b}$ that on acid hydrolysis affords $\mathbf{4}$. Thermal decomposition of the keto-ylid 65, obtainable from $O$-acetylsalicyloyl chloride and $\mathrm{Ph}_{3} \mathrm{P}=\mathrm{CHCO}_{2} \mathrm{Me}$, gives the ester $\mathbf{5 a}$ in $55 \%$ yield (Equation 6). ${ }^{45}$

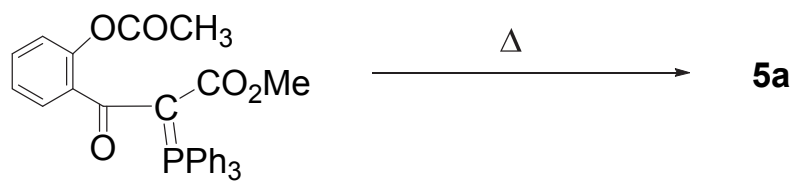

65

$\mathrm{Kim}^{46}$ has converted the 2-aroylquinol 66 into the benzopyran 68 via 67 (Scheme 8).

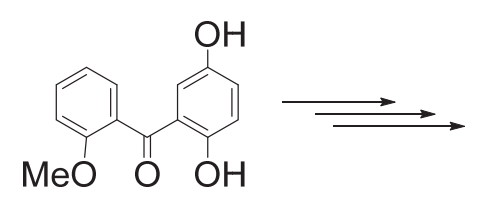

66

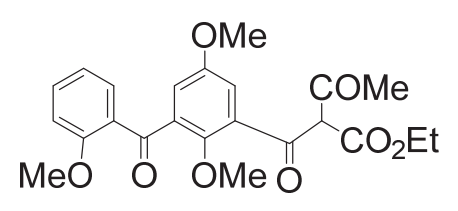

67

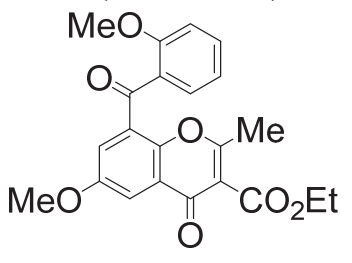

68

\section{Scheme 8}

The intermediate $\beta, \beta^{\prime}$-diketoester 70, resulting from 2-fluorobenzoyl chloride $\mathbf{6 9}$ and methyl acetoacetate in the presence of sodium hydride, undergoes cyclization via ipso-fluorine 
substitution to give the ester 5a. When the acid chloride 69 is similarly reacted with $t$-butyl acetoacetate and the reaction mixture treated with $\mathrm{HClO}_{4}$, the acid 4 results (Scheme 9). ${ }^{47}$

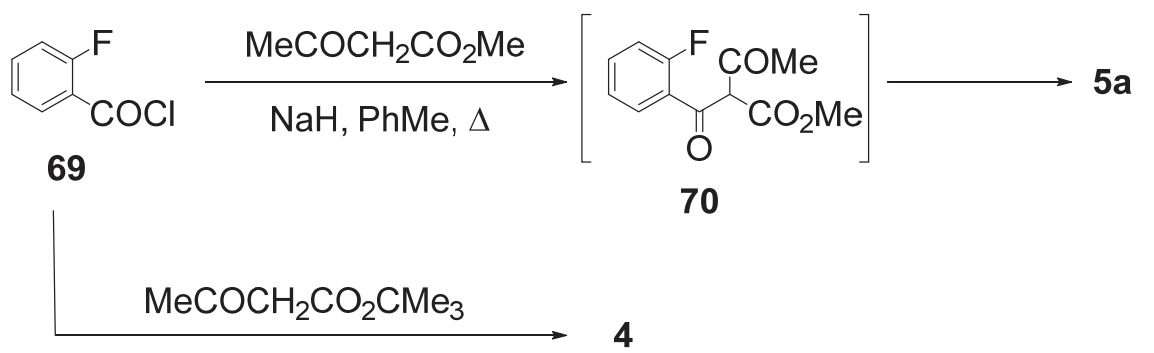

(i) $\mathrm{NaH}$, (ii) $\mathrm{PhMe}, \Delta$, (iii) $\mathrm{HClO}_{4}$

\section{Scheme 9}

A Russian group ${ }^{48-51}$ adopted this method for the preparation of tetrafluoro- and trifluorochromones 71 and extensively studied their reactions with several nitrogen nucleophiles. Lin and Long $^{52}$ subjected the $\beta$-ketoester 72 with $\mathrm{AcCl}$ in DMF containing $\mathrm{K}_{2} \mathrm{CO}_{3}$ and DIPEA to obtain the 7-fluorochromone derivative $\mathbf{7 3}$.

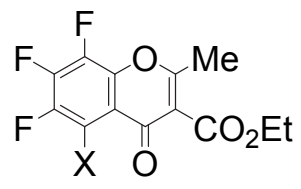

71a: $X=F$

b: $X=\mathrm{OH}$

c: $\mathrm{X}=\mathrm{OMe}$

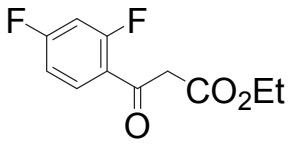

72

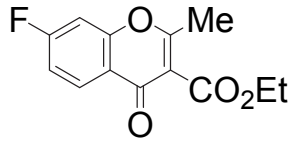

73

Preparation of the acid $\mathbf{4}$ and ester 5 from preformed chromone derivatives is also known. A mixture of 3-acetylchromone $\mathbf{6 b}, \mathrm{NH}_{2} \mathrm{OH} . \mathrm{HCl}$ and $\mathrm{NaOAc}$ on being heated under reflux in ethanol affords via $\mathbf{7 4}$ the nitrile $\mathbf{7 b}$ that can be converted into $\mathbf{4}$ and $\mathbf{5}$ (Scheme 10). ${ }^{53}$

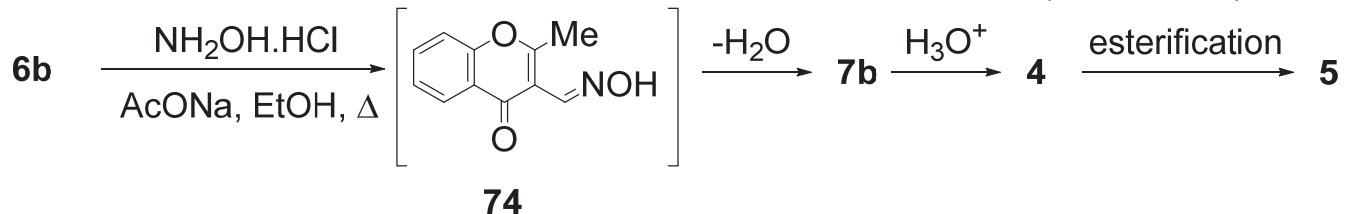

\section{Scheme 10}

Sequential rapid addition of diethyl carbonate and 2,6-dimethylchromone 63 to a solution of LDA at $-78^{\circ} \mathrm{C}$ produces the ester $75(42 \%)$ and the bis-hetaryl ketone 76 (17\%) arising from acylation of the intermediate chromone carbanion with diethyl carbonate and the ester $\mathbf{7 5}$, respectively. ${ }^{42,54}$ 
<smiles>CCOC(=O)c1c(C)oc2ccc(C)cc2c1=O</smiles>

75

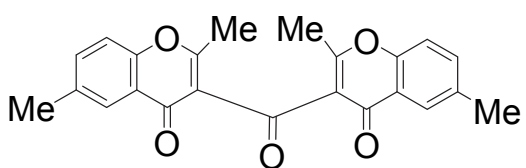

76

The 2-unsubstituted chromone ester 77, an analogue of $\mathbf{6 e}$, has been converted into the corresponding 2-methylchromone $\mathbf{7 9}$ by a sequential conjugate addition (through $\mathbf{7 8}$ ) and dehydrogenation (Scheme 11). ${ }^{11}$

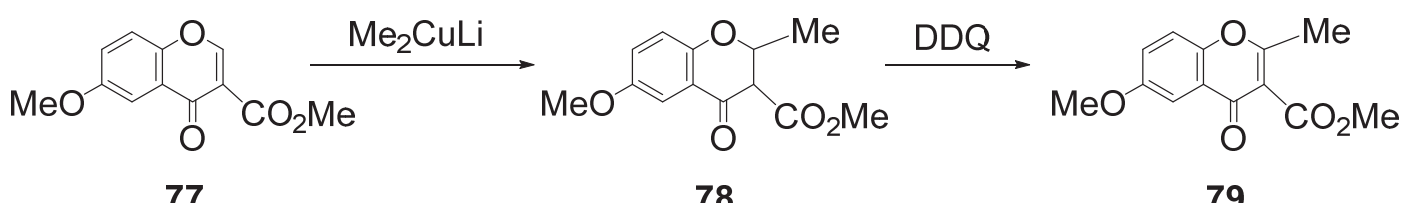

Scheme 11

\section{Conjugate Addition to the Pyran 2,3-Olefinic Bond of Chromones without Pyran Ring Opening}

\subsection{Conjugate reduction}

Conjugate reduction of chromone $\mathbf{3}$ with sodium borohydride in pyridine at room temperature is both regio- and chemo-selective giving the chromanone 80. Methanesulfonic acid triggers the pyranone ring opening of $\mathbf{8 0}$ followed by recyclization to give the 3-ethenylflavone $\mathbf{8 1} .^{36}$ The ester $5 \mathbf{a}$ with $\mathrm{NaBH}_{4}$ in methanol gives $\mathbf{8 2}$. $^{55}$

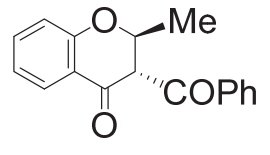

80

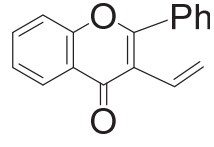

81

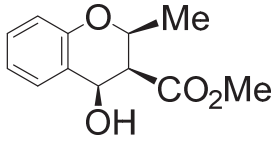

82

The conjugate reduction of the ester 5a to 84 followed by its Michael addition to an $\alpha, \beta$ unsaturated ketone $\mathbf{8 5}$, derived from a biocatalytic oxidation of methylcatechol $\mathbf{8 3}$ in a H-Cube Pro flow system, leading to the trisubstituted chromanone $\mathbf{8 6}$ (96\% yield; dr > 99:1) (Scheme 12) deserves special mention. ${ }^{56}$ 
<smiles>COC(=O)C(=C(OC)OC)c1ccccc1OC</smiles>

$5 a$

$+$<smiles>Cc1cccc(O)c1O</smiles>

83 (i) $20 \% \mathrm{Pd}(\mathrm{OH})_{2} / \mathrm{C}, 60 \% \mathrm{H}_{2}$ $7 \mathrm{~atm}, 22^{\circ} \mathrm{C}$

(ii) Laccase Ss1 from Streptomyces sviceus, $\mathrm{pH} 9$, air, $22^{\circ} \mathrm{C}$

\section{Scheme 12}

\subsection{Conjugate addition of alkyl and alkoxy groups}

Lithium dimethylcuprate in THF at $-10^{\circ} \mathrm{C}$ transforms 3-acyl- and 3-carbomethoxy-chromone 2 and $\mathbf{5 a}$ to the corresponding 2,2-dimethylchromanone derivatives $87\left(\mathrm{R}=\mathrm{Me}\right.$ or $\mathrm{OMe} ; \mathrm{R}^{1}=$ Me). ${ }^{11,57,58}$ Clarke et al. ${ }^{11}$ have treated the ester 5a with lithium $n$-butylcuprate to get the chromanone 88, assumed to have the larger $n$-butyl and ester substituents in trans-diequatorial orientation. The compound $87\left(\mathrm{R}=\mathrm{OMe} ; \mathrm{R}^{1}=\mathrm{Me}\right)$ on treatment with $\mathrm{NaCl}$ in $\mathrm{DMSO}$ at $155^{\circ} \mathrm{C}$ gives 2,2-dimethylchromanone $\mathbf{8 9},{ }^{57}$ the latter being also provided by treating 2-methylchromone with methylcopper-BF 3 complex. ${ }^{11}$

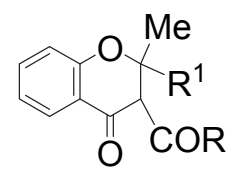

87: $\mathrm{R}=\mathrm{Me}, \mathrm{OMe} ; \mathrm{R}^{1}=\mathrm{Me}$

88: $\mathrm{R}=\mathrm{OMe} ; \mathrm{R}^{1}=n-\mathrm{Bu}$

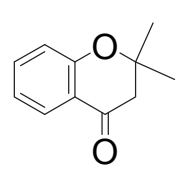

89

Crombie et al. ${ }^{59,60}$ have developed a conjugate addition - radical cyclization approach to construct the naturally occurring sesquiterpene-phenol carbon framework. To an ether - pentane solution of the mixed ligand cuprate reagent 92, derived from the alkyl iodide 90, lithium cuprate 91 and $t$-butyllithium, was added the ester 5a to obtain the chromanone $\mathbf{9 3}$ as a mixture of four stereoisomers. Treatment of this mixture with $\mathrm{Mn}(\mathrm{OAc})_{3}$-HOAc affords the hemiacetal 94 in $30 \%$ yield (Scheme 13). In another approach the 2-alkyl ester 96 prepared from 2-fluorobenzoyl chloride 69 and the ester 95, is converted into the 2,2-dialkylated chromanone 97 by treatment with $\mathrm{Me}_{2} \mathrm{CuLi}$. Radical cyclization of $\mathbf{9 7}$ as an unresolved stereoisomeric mixture affords the polycyclic lactone 98 in nearly $30 \%$ yield (Scheme 14). ${ }^{59,60}$ 


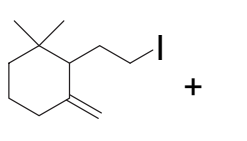

90<smiles>CC(Cl)(C#N)C1C=CS1</smiles>

91

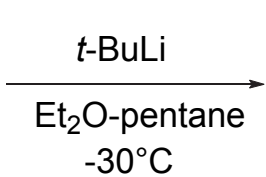

$-30^{\circ} \mathrm{C}$<smiles>C=C1CCCC(C)(C)C1CCCC(NCCN)C(C)(C)C</smiles>

92
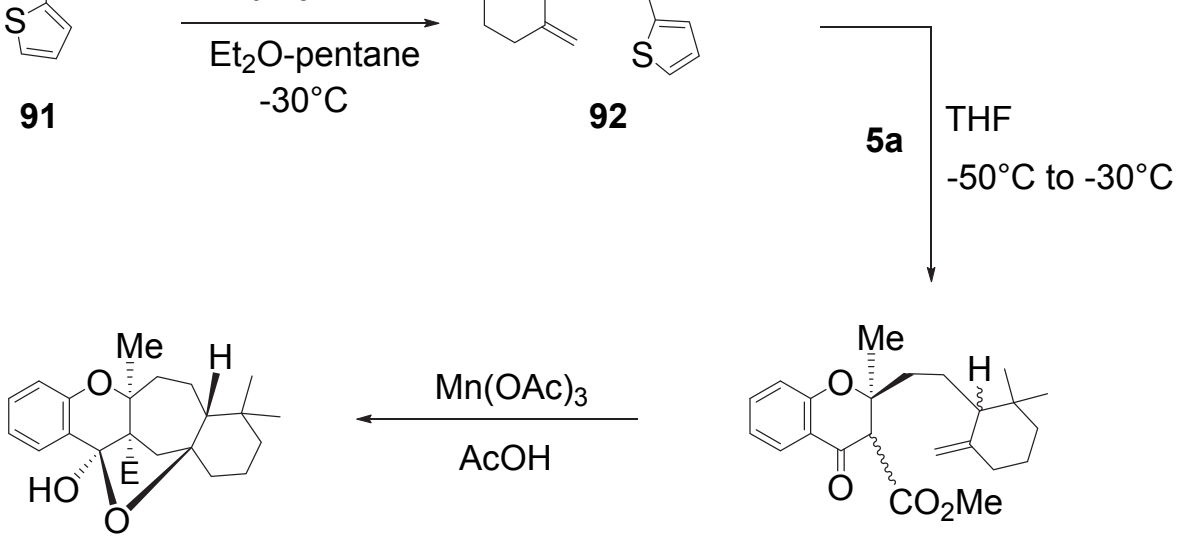

$94: \mathrm{E}=\mathrm{CO}_{2} \mathrm{Me}$

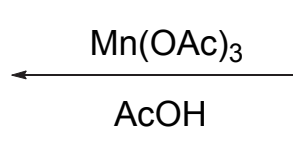

$\mathrm{AcOH}$

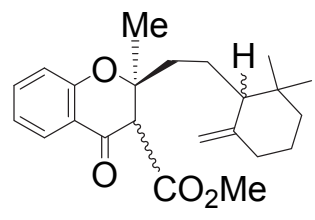

93

\section{Scheme 13}

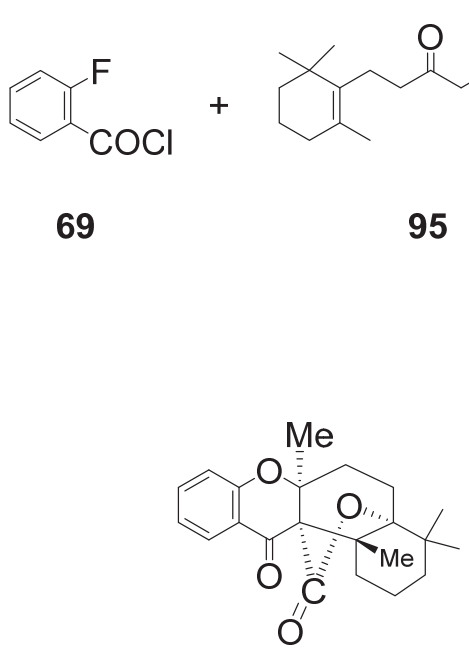

98
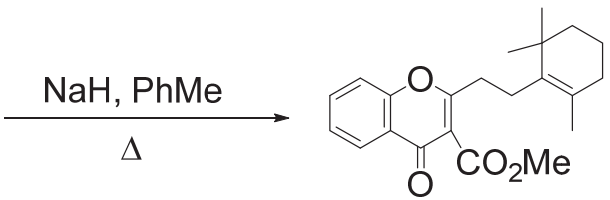

96

$\mathrm{Me}_{2} \mathrm{CuLi}$

THF-Et ${ }_{2} \mathrm{O}$ $-10^{\circ} \mathrm{C}$
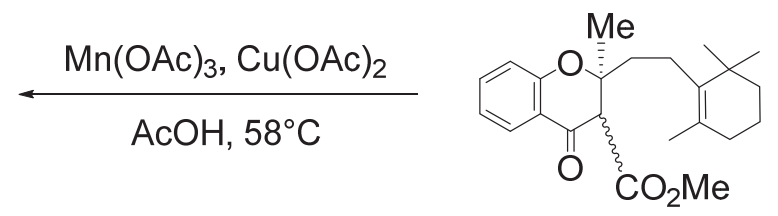

97

\section{Scheme 14}

A lithium dialkynylcuprate as $\left[(\mathrm{TMS}-\mathrm{C} \equiv \mathrm{C})_{2} \mathrm{CuLi}\right]$, though capable of transferring its alkynyl group in a conjugate addition to the ester $\mathbf{6 e}$, failed to react with 3-alkoxycarbonyl-2methylchromone $\mathbf{5}^{61}$

3-Acetylchromone $\mathbf{2}$ on treatment with the silyl enol ether $\mathbf{9 9}$ in the presence of trimethylsilyl triflate (TMSOTf) affords in 16\% yield the chromonanone $\mathbf{1 0 0}$ as a diastereoisomeric mixture (Equation 7). ${ }^{62}$ 


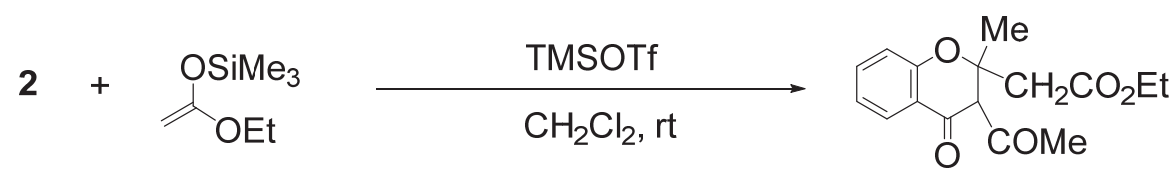

99

100

Heteroannulation of the chromone $\mathbf{A}(\equiv \mathbf{2}, \mathbf{3}, \mathbf{5 a})$ with 2-chloroethanol in the presence of $\mathrm{K}_{2} \mathrm{CO}_{3}$ to the corresponding furobenzopyranone 101 (Equation 8) proceeds via the conjugate addition of the haloethanol to the chromone followed by intramolecular alkylation. ${ }^{63}$ Transformation of the chromone ester 102 on treatment with $\mathrm{MeI}-\mathrm{K}_{2} \mathrm{CO}_{3}$ in refluxing acetone into the spiroacetals $\mathbf{1 0 3}$ and $\mathbf{1 0 4}$ in a ratio of 5:1 (in 60\% total yield) (Equation 9) also involves a sequential intramolecular conjugate addition and enolate alkylation. ${ }^{64}$

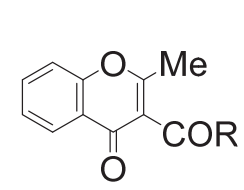

$A: \mathrm{R}=\mathrm{Me}, \mathrm{Ph}, \mathrm{OMe}$

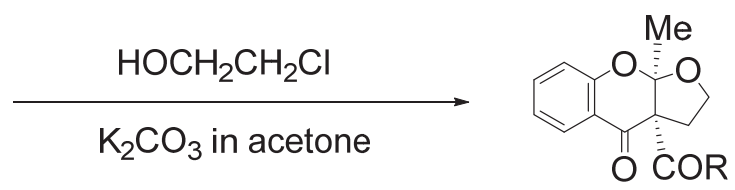

101

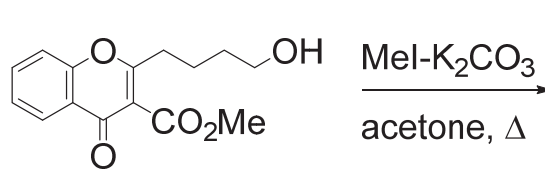

102

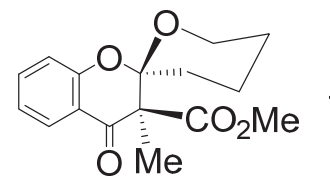

103

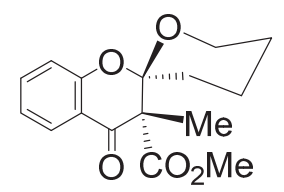

104

Alkaline hydrogen peroxide with the esters 5a and $\mathbf{1 0 2}$ forms the epoxides $\mathbf{1 0 5}$ and $\mathbf{1 0 6}$, respectively. Acid catalyzed oxirane ring opening of 106 results in the formation of the spiroacetals 107 and 108 (Scheme 15). ${ }^{64}$<smiles>[R]c1oc2ccccc2c(=O)c1C(=O)OC</smiles>

5a: $\mathrm{R}=\mathrm{Me}$

102: $\mathrm{R}=\mathrm{CH}_{2}\left(\mathrm{CH}_{2}\right)_{3} \mathrm{OH}$

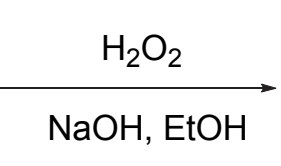

$$
\begin{aligned}
& \text { 105: } \mathrm{R}=\mathrm{Me} \\
& \text { 106: } \mathrm{R}=\mathrm{CH}_{2}\left(\mathrm{CH}_{2}\right)_{3} \mathrm{OH}
\end{aligned}
$$

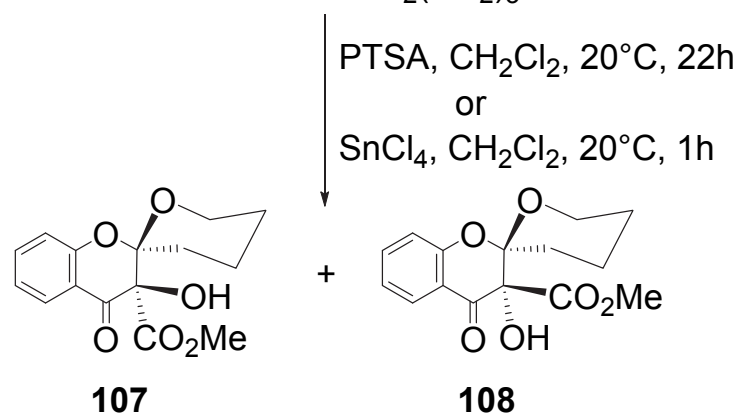

\section{Scheme 15}




\section{Conjugate Addition with Other Concomitant Reactions}

\subsection{Addition of ammonia and amines}

The aza-Michael adduct 110 resulting from tetrafluorobenzopyran-3-carboxylic acid 109 and ammonia undergoes decarboxylative pyran ring opening to give the enaminoketone 111 that on acid treatment affords 2-methylchromone 112 (Scheme 16). ${ }^{65}$ Piperidine brings about substitution of fluorine at the 7-position of $\mathbf{1 0 9}$ and conjugate addition, the adduct $\mathbf{1 1 3}$ undergoing decarboxylative elimination of the piperidine moiety to give $\mathbf{1 1 4}$ (Scheme 16). ${ }^{65}$<smiles></smiles><smiles>C[C@H](CC(=O)O)N1CCCCC1</smiles>

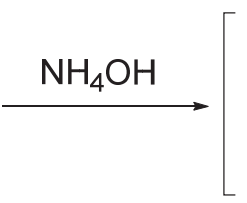<smiles>CC1(N)Oc2c(F)c(F)c(F)c(F)c2C(=O)C1C(=O)O</smiles>

110<smiles>C/C(N)=C\C(=O)c1c(C)cc(O)c(F)c1F</smiles>

111<smiles>[X]c1c(F)c(F)c2c(=O)cc(C)oc2c1F</smiles>

112: $X=F$

114: $X=N$

\section{Scheme 16}

The ester 5 with the amine $\mathrm{RNH}_{2}\left(\mathrm{R}=\mathrm{H}, \mathrm{Me}, \mathrm{PhCH}_{2}, \mathrm{CH}_{2} \mathrm{CH}_{2} \mathrm{OH}\right)$ gives the benzopyran2,4-dione 115, its enol tautomeric form 116 functioning as a ligand to form $\mathrm{Pd}(\mathrm{II})$ complex of the general formula $\mathrm{PdL}_{2}\left(\mathrm{~L}=\right.$ deprotonated 116) ${ }^{66-69}$ This four co-ordinated $\mathrm{Pd}(\mathrm{II})$ complex 117 exists in cis-isomeric form for the ligand $\mathrm{L}(\mathrm{R}=\mathrm{H})$ and trans-form for $\mathrm{L}(\mathrm{R}=$ other than $\mathrm{H}) .{ }^{67,68}$ Cytotoxic effects of the diones $\mathbf{1 1 5}$ and several of their $\mathrm{Pd}(\mathrm{II})$ complexes have been assessed against two leukemia cell lines HL-60 and NALM-6. On treatment with $\mathrm{RNH}_{2}(\mathrm{R}=\mathrm{H}, \mathrm{Me}$, $\mathrm{PhCH}_{2}$, hexyl, cyclohexyl etc.), the fluorinated chromone-3-ester 118a gives 4-hydroxycoumarin $\mathbf{1 1 9 a},{ }^{48,51,70} \mathbf{1 1 8 b}$ affords $\mathbf{1 1 9 b},{ }^{71} \mathbf{1 1 8 c}$ provides $119 \mathbf{c}^{49,51}$ and $\mathbf{1 1 8 d}$ the coumarin $\mathbf{1 1 9 d}{ }^{72}$ 
<smiles>[R]NC(C)=C1C(=O)Oc2ccccc2C1=O</smiles>

115<smiles>[Y]c1oc2c(F)c([X])c(C(=O)OCC)c(=O)c-2c([X])c1F</smiles>

118<smiles>[R]NC(C)c1c(O)c2ccccc2oc1=O</smiles>

116<smiles>[R]N1C(=O)c2c(oc3ccccc23)O[Pb]1O</smiles>

117
For 118 and 119

a: $X=Y=F$

b: $X=H, Y=F$

c: $X=O M e, Y=F$

d: $X=\mathrm{H}, Y=\mathrm{SCH}_{2} \mathrm{CH}_{2} \mathrm{OH}$

\subsection{Addition of nitrogenous dinucleophiles}

4.2.1. Dinucleophiles having adjacent nucleophilic centres. A dinucleophile as $\mathbf{1 2 0}$ undergoes aza-Michael addition to 3-acetyl-2-methylchromone 2 with concomitant opening of the pyran ring to form the intermediate $\mathbf{1 2 1}$ in $Z$-isomeric form so that its acetyl carbonyl group is protected as a hemiacetal 122, the latter having no other way than to cyclize to the heterocycle 123 (Scheme 17). ${ }^{73}$

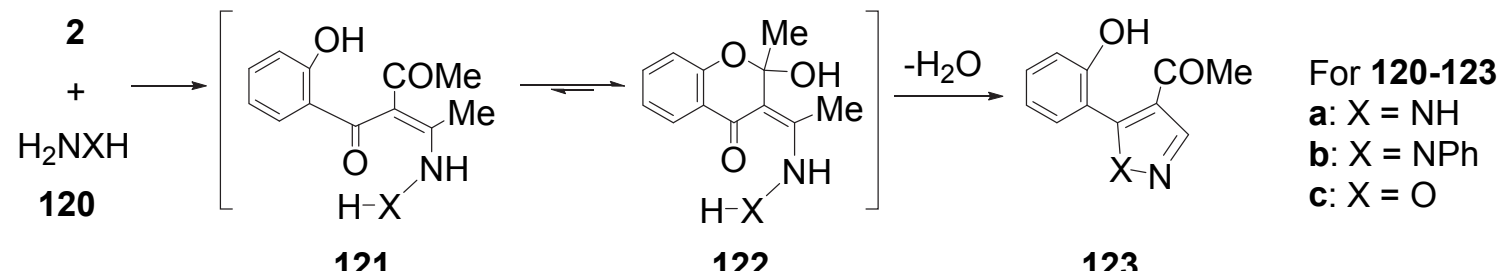

\section{Scheme 17}

Reaction of phosphonic dihydrazide $\mathbf{1 2 4}$ and chromone $\mathbf{2}$ in a 1:2 molar ratio gives, probably through a domino aza-Michael addition - pyran ring opening - recyclization, the intermediate $\mathbf{1 2 5}$ that reacts further with a second molecule of $\mathbf{2}$ in the same reaction sequence giving the bis-hydrazone $\mathbf{1 2 6}$ as the final product (Scheme 18). ${ }^{74}$

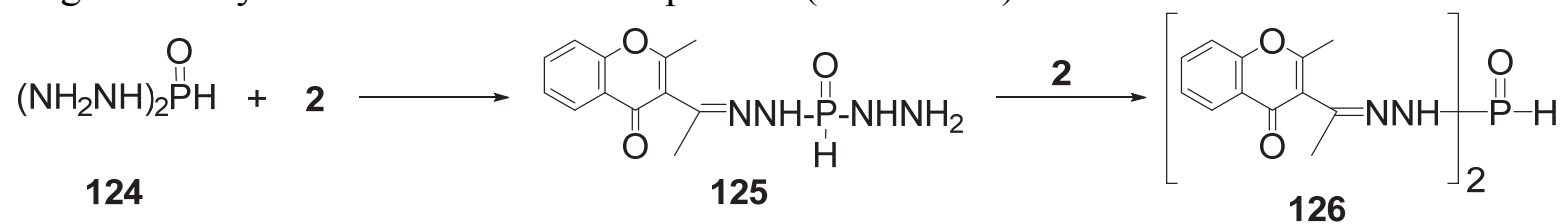

\section{Scheme 18}

A mixture of 6-formylfurochromone $\mathbf{1 6}$ and 2-cyanoacethydrazide $\mathbf{1 2 7}$ in a 1:1 molar ratio on stirring in $\mathrm{AcOH}$ at ambient temperature gives the hydrazone $\mathbf{1 2 8}$ by direct derivatization of the aldehyde function of $\mathbf{1 6}$ with hydrazide 127. The hydrazone $\mathbf{1 2 9}$ is formed on similar 
treatment of the ketone $\mathbf{5 9}$ with the hydrazide 127 probably through a domino aza-Michael addition - pyran ring opening - recyclization sequence. When refluxed separately in acetic acid, the hydrazones 128 and 129 cyclize by intramolecular Michael addition giving respectively the benzopyran-3-ylpyrazolidones $\mathbf{1 3 0}$ and $\mathbf{1 3 1}$ which can further react with a second molecule of 127 in boiling acetic acid to yield the bis-pyrazolidones 132 and 133, respectively (Scheme 19). ${ }^{75}$
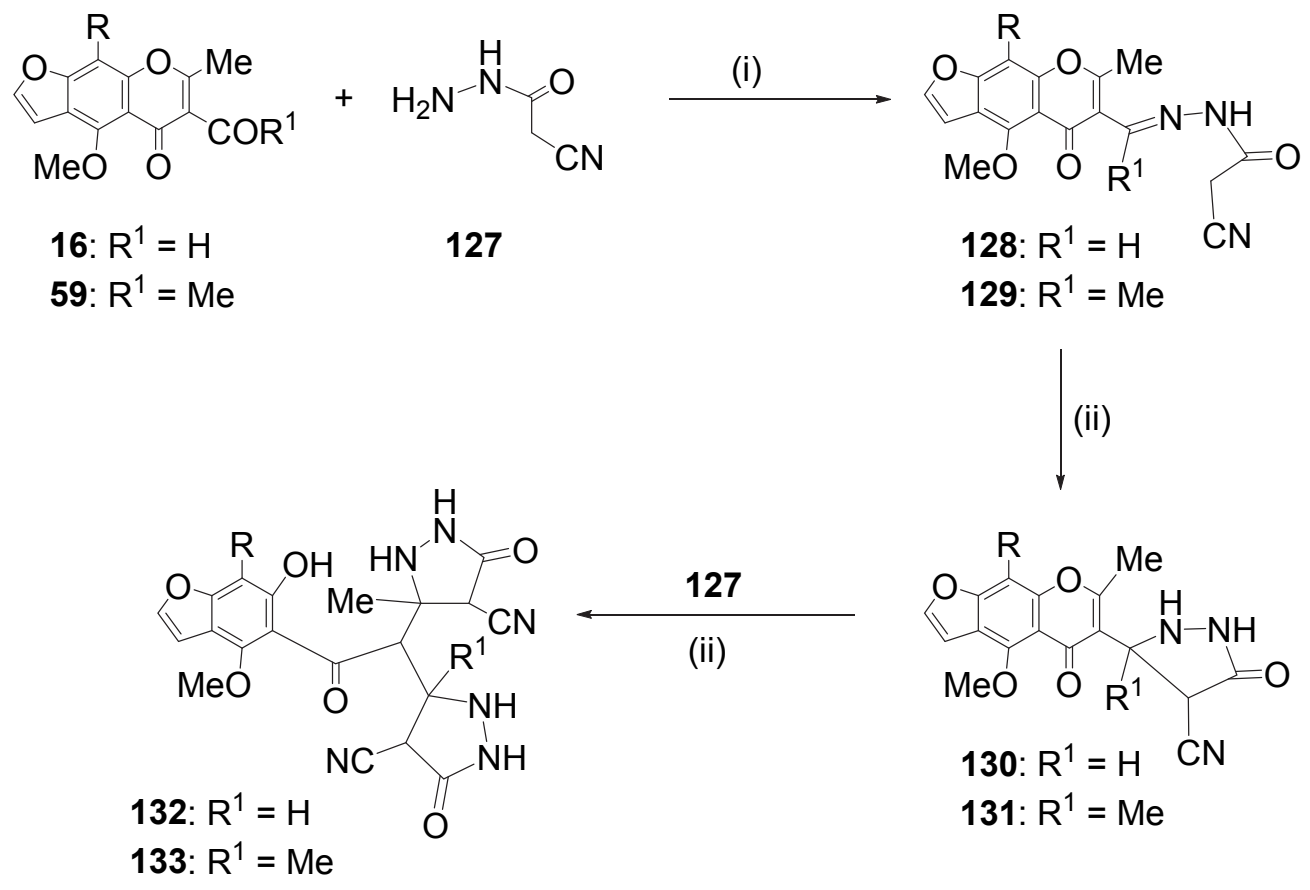

For $\begin{aligned} 16,59 \text { and } 128-133 \text { a: } R & =H \\ \text { b: } R & =O M e\end{aligned}$

Scheme 19. Conditions : (i) Stirring in 95\% AcOH, in a 1:1 molar ratio, rt; (ii) AcOH, reflux.

3-Benzoylchromone 3 behaves similarly to its 3-acetyl analogue 2 towards hydrazines. For example, the chromone $\mathbf{1 3 4}$ with semicarbazide or (thio)semicarbazide $\mathrm{H}_{2} \mathrm{NNHC}(=\mathrm{X}) \mathrm{NH}_{2}$ in refluxing methanol gives the tetrasubstituted pyrazole $\mathbf{1 3 5}^{76}$<smiles>CC(Oc1ccc(Cl)cc1C)=C(C)C(=O)c1ccccc1</smiles>

134<smiles>[X]C(N)n1nc(C)c(C(=O)c2ccccc2)c1-c1cc(Cl)ccc1O</smiles>

$135: X=O$ or $S$

Phenylhydrazine undergoes 1,4-addition to the $\alpha, \beta$-unsaturated acid 4; the adduct 136 may give either the coumarinopyrazole 138 through its pyran ring opening (to 137) and recyclization 
(Scheme 20-path $a$ ) or the trisubstituted pyrazole 140 through a Grob fragmentation (to 139) and cyclization (path $b$ ). A French group ${ }^{77}$ have reported without disclosing the experimental details the formation of $\mathbf{1 3 8}$ in the said reaction, whereas Ghosh and $\mathrm{Pal}^{53}$ obtained exclusively the pyrazole 140 by heating under reflux a mixture of 4 and $\mathrm{PhNHNH}_{2} \cdot \mathrm{HCl}$ in ethanol containing sodium acetate. The acid 4 with $\mathrm{NH}_{2} \mathrm{OH}$ follows a reaction course similar to Scheme 20-path $b$ to yield the isoxazole $141 .^{78}$

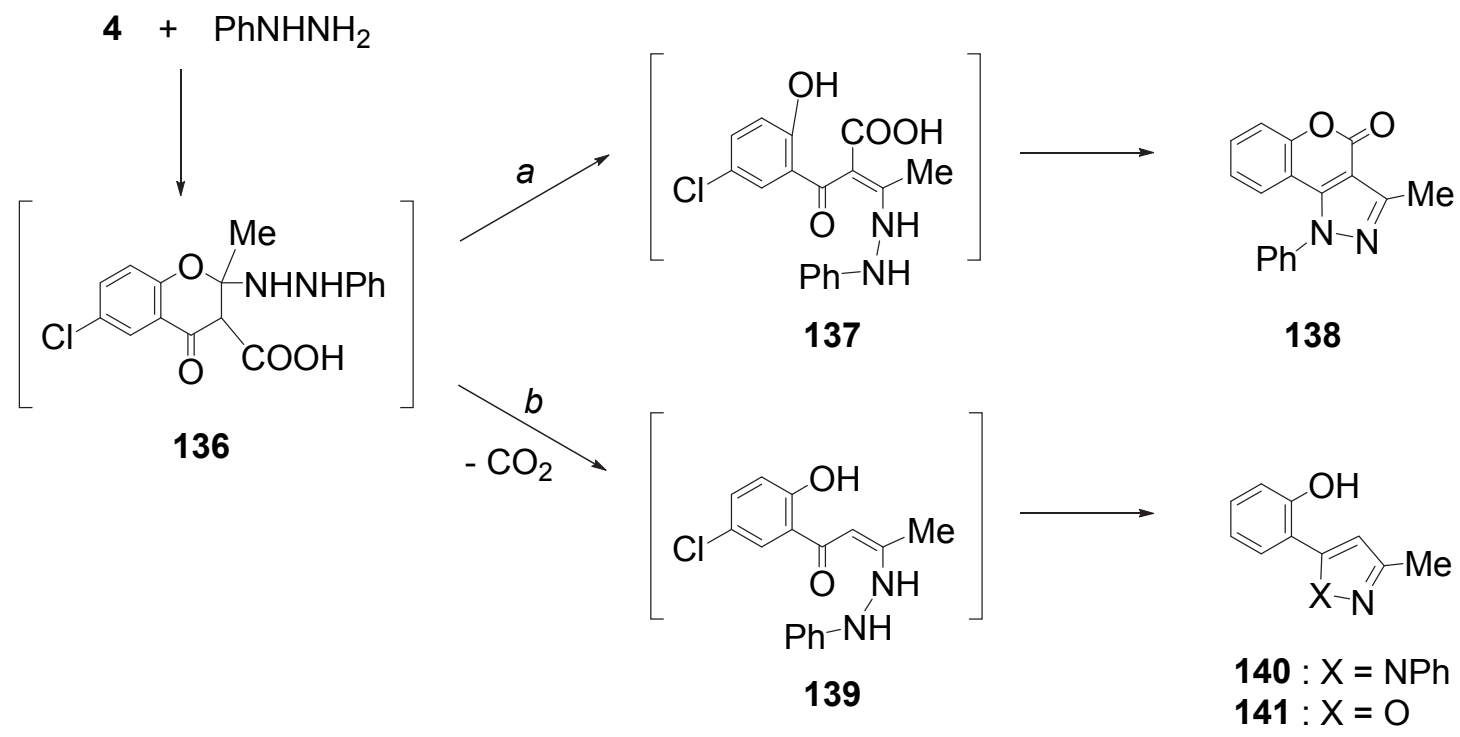

\section{Scheme 20}

The ester 5a with methylhydrazine 142a gives 144a (20\%) and 145a (64\%), the former product (144a) arising by lactonization of the non-isolable intermediate 143a and the latter (145a) lactonizing to $\mathbf{1 4 6 a}$ only by base (like triethylamine) treatment (Scheme 21). ${ }^{79,80}$ Both 144a and 145a can serve as ligand $\mathrm{L}$ to form with $\mathrm{Pd}(\mathrm{PhCN})_{2} \mathrm{Cl}_{2}$ trans $-\mathrm{PdL}_{2} \mathrm{Cl}_{2}$ complexes, only the doubly-bonded nitrogen of $\mathrm{L}$ being co-ordinated to $\mathrm{Pd}(\mathrm{II}){ }^{79,80}$ Treatment of the ester $\mathbf{5 a}$ with 2-hydrazinopyridine 142b gives exclusively the 1-(2-pyridyl)pyrazole 145b that forms with $\mathrm{K}_{2} \mathrm{PtCl}_{4}, \mathrm{~K}_{2} \mathrm{PdCl}_{4}$ and $\mathrm{CuCl}_{2}$ the metal complex of the general formula 147. A molecule of dimethylformamide can also coordinate with $\mathrm{Cu}$ (II) of the complex $147(\mathrm{M}=\mathrm{Cu})$ giving the pentacordinated $\mathrm{Cu}$ (II) complex 148. ${ }^{81,82}$ The structures of all these metal complexes have been confirmed by X-ray analysis. 


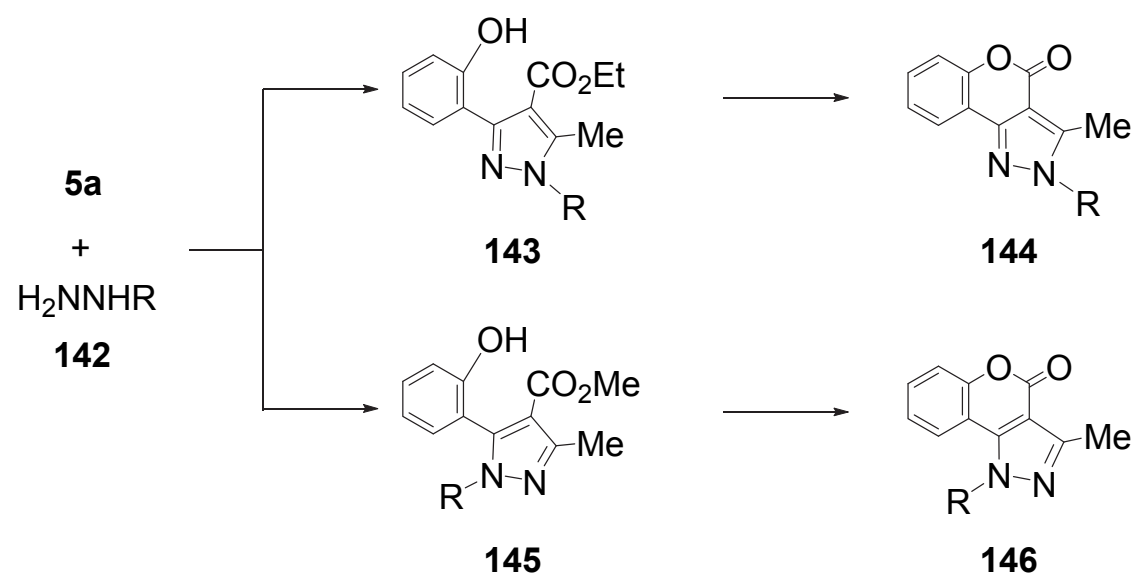

For 142-146 a: $\mathrm{R}=\mathrm{Me}$

b: $R=2$-pyridyl

Scheme 21<smiles></smiles>

147<smiles></smiles>

148

For 147 and 148: $\mathrm{Ar}=2-\mathrm{HO}-\mathrm{C}_{6} \mathrm{H}_{4}$

4.2.2. Dinucleophiles with two nucleophilic centres separated by one carbon. Guanidine undergoes conjugate addition to the chromone 2 with concomitant opening of the pyran ring; the resultant intermediate 149, unlike $\mathbf{1 2 1}$ arising from 2 and hydrazine or hydroxylamine, undergoes $[6+0]$ cyclization involving the acetyl, not aroyl, group giving the pyrimidine 150 (Scheme 22). ${ }^{73}$ In a precisely similar way, the amino group of 5-amino- $1 H$-pyrazoles 151 attacks at C-2 of 3benzoylchromone 3 with subsequent opening of the pyran ring; the resultant intermediate 152 cyclizes to the pyrazolopyrimidine $\mathbf{1 5 3}$ (Scheme 23). ${ }^{83}$ This reaction under microwave irradiation and solvent free conditions gives high yields of the products.

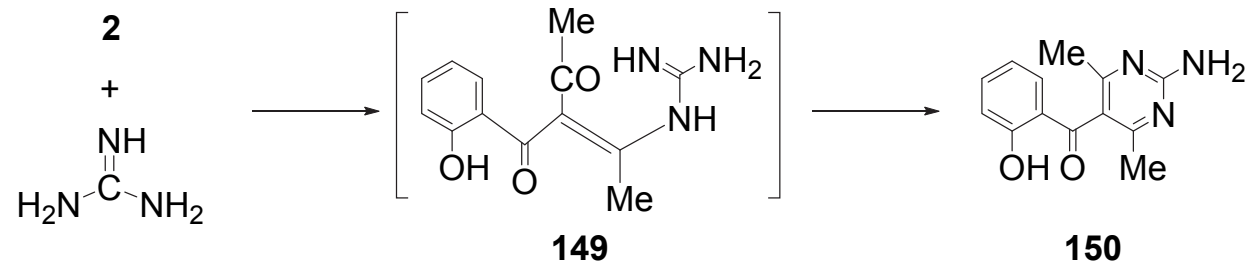

\section{Scheme 22}




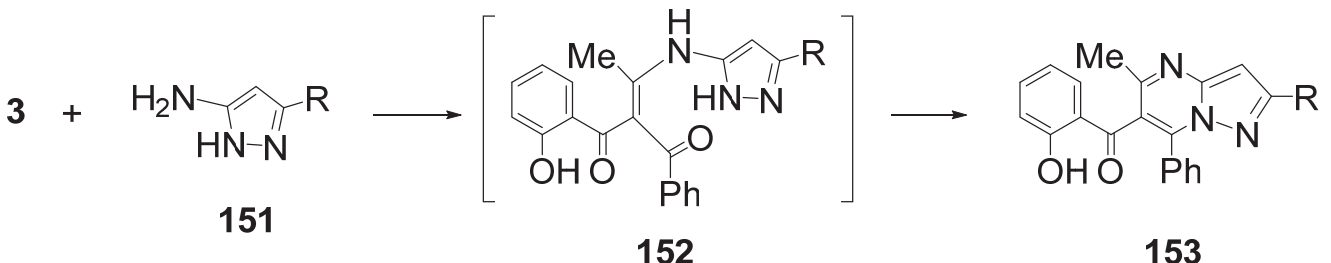

$$
\begin{aligned}
& \text { For } 151-153: \mathrm{R}=\mathrm{Me}, t-\mathrm{Bu}, \mathrm{Ph}, 4-\mathrm{X}-\mathrm{C}_{6} \mathrm{H}_{4} \text {, } \\
& \mathrm{X}=\mathrm{Me}, \mathrm{MeO}, \mathrm{Cl}, \mathrm{Br}
\end{aligned}
$$

\section{Scheme 23}

4.2.3. Dinucleophiles with two nucleophilic centres separated by two carbons. No plausible mechanism has been suggested for the formation of the benzimidazole $156^{65}$ and benzothiazole $\mathbf{1 5 7 ^ { 8 4 , 8 5 }}$ by treating the tetrafluorinated ester 118a respectively with $o$-phenylenediamine $\mathbf{1 5 4}$ and 2-aminothiophenol 155 in boiling ethanol. Later Li et al. ${ }^{86}$ reported that the product 157, if prepared from 118a and 155, remains admixed with the benzothiazole 158; it can be had exclusively by treating the acid chloride 159 with the thiophenol 155 in $N$-methyl-2-pyrrolidone at $100{ }^{\circ} \mathrm{C}$. A mixture of $\mathrm{Zn}(\mathrm{OAc})_{2}$ and potassium salt of thiazole $\mathbf{1 5 7}$ in a molar ratio of 1:2 in $\mathrm{MeOH}-\mathrm{H}_{2} \mathrm{O}$ forms the four coordinated $\mathrm{Zn}(\mathrm{II})$ complex $\mathbf{1 6 0} .^{86}$

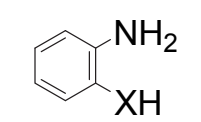

$154: \mathrm{X}=\mathrm{NH}$

$155: X=S$

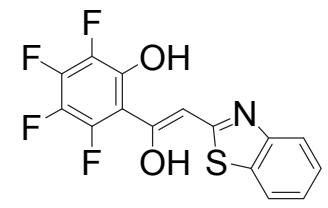

158

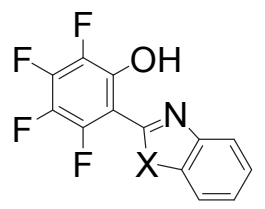

$156: X=\mathrm{NH}$

$157: X=S$<smiles>COc1c(F)c(F)c(F)c(F)c1C(=O)Cl</smiles>

159

\subsection{Addition of carbon nucleophiles}

Miky and Sharaf ${ }^{30}$ have reported, without giving any mechanistic interpretation, the reaction of 6-acetyl-visnagin and -khellin 59 separately with cyanoacetamide, $\alpha$-cyanothioacetamide, malononitrile and ethyl cyanoacetate in the presence of $\mathrm{NH}_{4} \mathrm{OAc}$, yielding respectively the tetracyclic compounds $162 \mathrm{a}-\mathbf{d}$ or their isomers 162 'a-d. The formation of $\mathbf{1 6 2}$ is conceptualized by a domino base catalyzed conjugate addition of the active methylene compound 161 to 59 pyran ring opening - recyclization (to 163) - amination (to 164) - cyclization sequence (Scheme 24). The formation of $\mathbf{1 6 2}$ ', necessitating a highly unlikely 1,2-addition of $\mathbf{1 6 1}$ to a very poor electrophilic centre C-5 of $\mathbf{5 9}$ is, therefore, ruled out. 


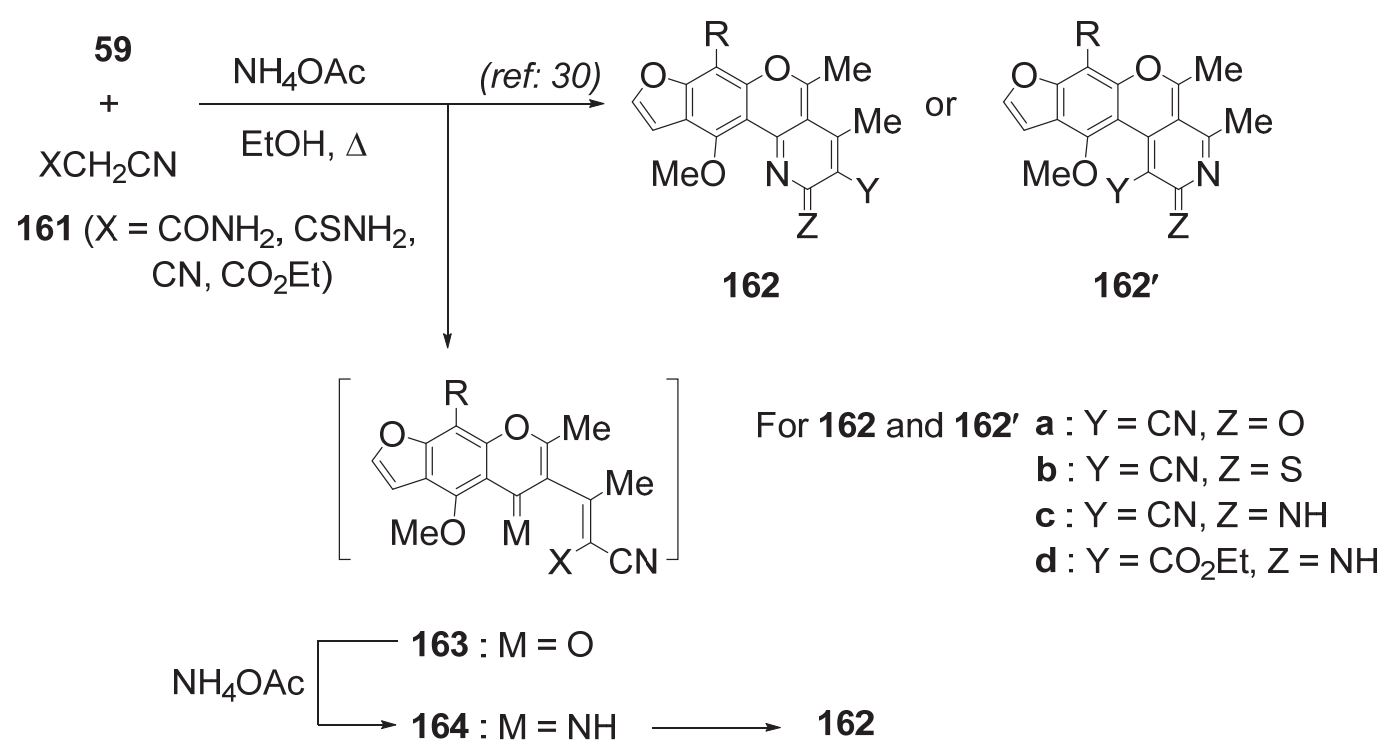

\section{Scheme 24}

6-Acetylfurochromone 59 reacts with $N^{\prime}$-acetyl-2-cyanoacetohydrazide 165 in dioxane containing triethylamine to afford the hetarylpyrazolidinone 168 via the intermediates 166 and 167 (Scheme 25). ${ }^{75}$

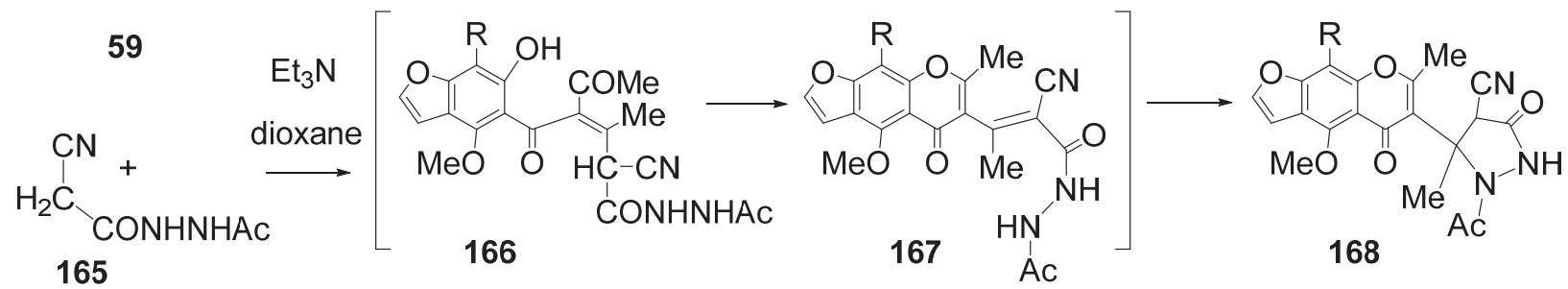

\section{Scheme 25}

\section{Bromination of 3-Acyl-2-methylchromones 2 and 3, and Reactions of the Resultant Bromo Derivatives}

3-Acetyl-2-methylchromone $\mathbf{2}$ and its analogues on bromination with bromine ${ }^{30,87-90}$ as well as with phenyltrimethylammonium tribromide ${ }^{91}$ give the corresponding 3-bromoacetylchromones (Equation 10), the latter reagent being claimed to improve the yield.<smiles>COC1=C(C(C)=O)C(=O)c2ccccc21</smiles>

2

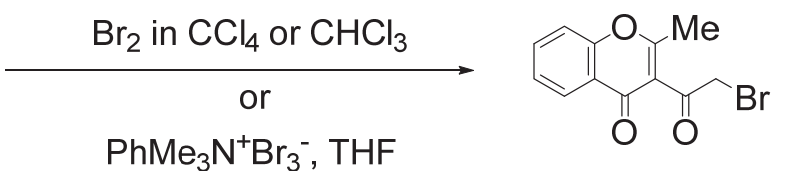

169 
The chromone 170 involves only its bromoacetyl moiety, very rarely the pyran ring, in its reaction with thiourea as well as thio-acid amide $\mathbf{1 7 1}$ to give the benzopyran-3-ylthiazole $\mathbf{1 7 2} .^{87}$ The thiazole $172\left(\mathrm{R}^{1}=\mathrm{NH}_{2}\right)$ condenses with aryl bromomethyl ketone 173 giving imidazolothiazole 174 (Scheme 26). ${ }^{88}$

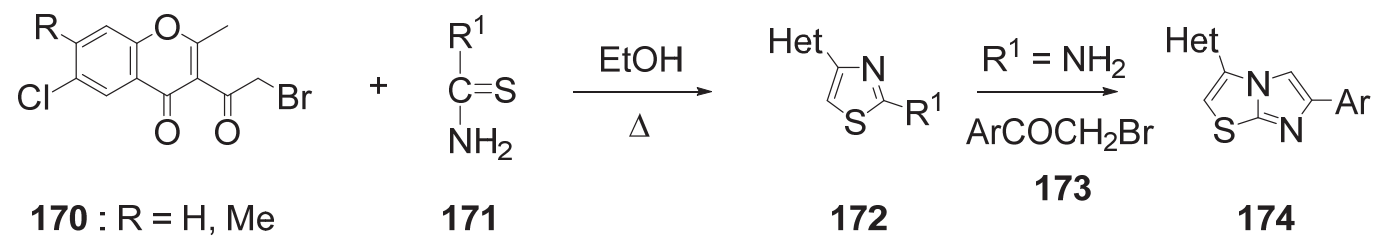

For 171 and $172: \mathrm{R}^{1}=\mathrm{NH}_{2}, \mathrm{Ph}, \mathrm{NHPh}, 4-\mathrm{X}-\mathrm{C}_{6} \mathrm{H}_{4} ; \mathrm{X}=\mathrm{Me}, \mathrm{Cl}, \mathrm{NO}_{2}$

For 173 and $174: \mathrm{Ar}=\mathrm{Ph}, 4-\mathrm{X}-\mathrm{C}_{6} \mathrm{H}_{4} ; \mathrm{X}=\mathrm{Me}, \mathrm{Cl}, \mathrm{NO}_{2}$

For 172 and $174:$ Het $=$<smiles>[R]c1ccc2c(c1)OC(C)(C(C)(C)C)C(=O)C2</smiles>

\section{Scheme 26}

The reaction between the chromone $\mathbf{1 7 5}$ and pyrazole-1-thiocarboxamide $\mathbf{1 7 6}$ leads to the product 177 incorporating three different heterocyclic systems (Equation 11). ${ }^{89}$

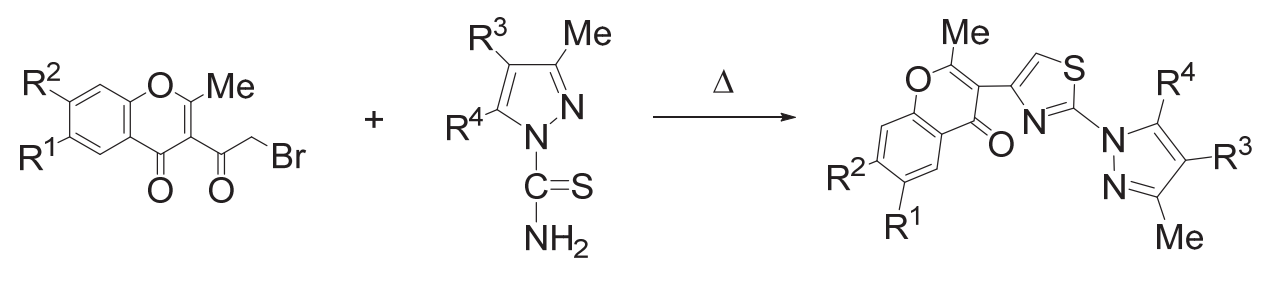

175

176

177

For 175 - 177: $\mathrm{R}^{1}=\mathrm{H}, \mathrm{Me}, \mathrm{Cl} ; \mathrm{R}^{2}=\mathrm{H}, \mathrm{Me} ; \mathrm{R}^{3}=\mathrm{H}, \mathrm{Me}, \mathrm{Et} ; \mathrm{R}^{4}=\mathrm{Me}$, 2-thienyl, 3-furyl

The thiourea skeleton incorporated within the imidazole-2-thiol $\mathbf{1 7 8}$ condenses with the bromoacetyl moiety of 169 giving the imidazolothiazole 179 (Equation 12). ${ }^{90}$ Bromine function of 7-fluoro-3-bromoacetyl-2-methylchromone can be substituted by primary and secondary alkyl or aryl amines. ${ }^{91}$

169<smiles>Sc1ncc(Br)[nH]1</smiles><smiles>Cc1oc2ccccc2c(=O)c1-c1csc2nc(Br)cn12</smiles>

179 
Ghosh et al. ${ }^{92}$ have studied the reactions of 3-bromoacetyl-2-methylchromone 169 with some dinucleophiles (Scheme 27). The chromone 169 with thioacetamide gives the expected thiazole 180. In contrast, thiourea with 169 in refluxing ethanol containing AcONa gives the pyrrolobenzopyran 182 without any trace of 181 . The chromone 169 produces [1]benzoxepino[4,3-d] isoxazole 183, [1]benzoxepino[3,4-c]pyrazole 184 and quinoxaline 185 with hydroxylamine, phenylhydrazine and $o$-phenylenediamine, respectively.

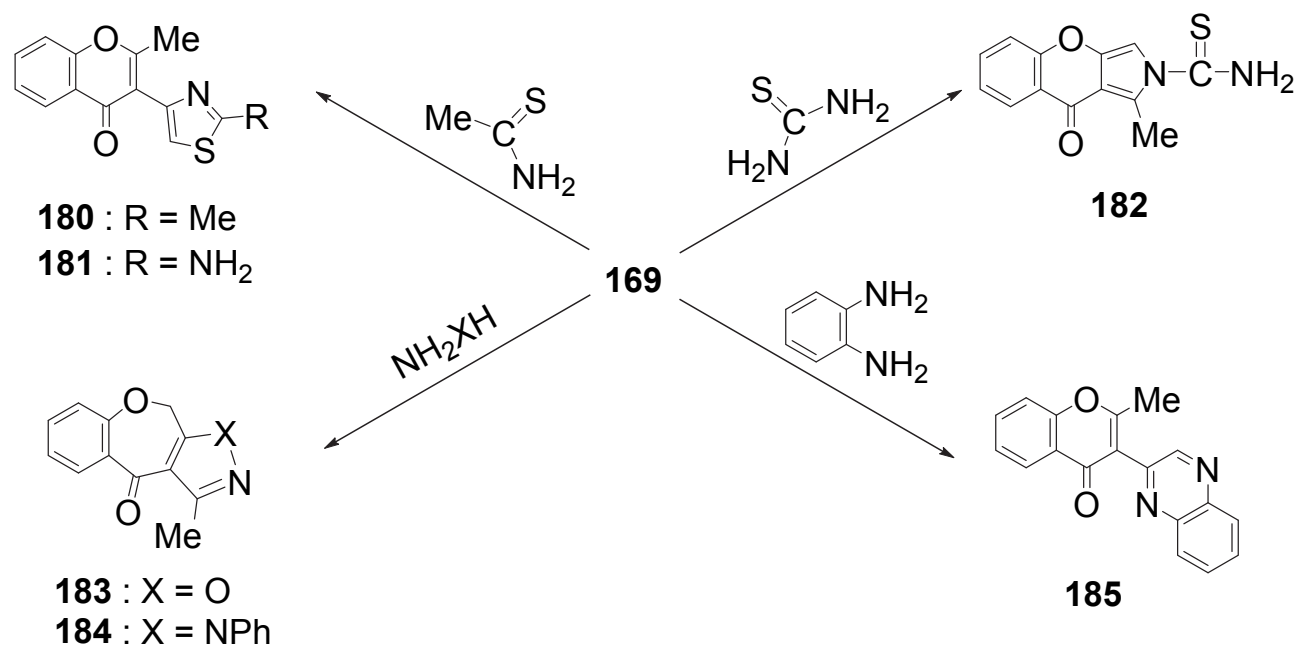

\section{Scheme 27}

3-Benzoyl-2-methylchromone $\mathbf{3}$ is brominated by bromine to the 2-bromomethylchromone 186; it can be transformed into 187 by treatment with AcONa in refluxing ethanol. ${ }^{93}$ The chromone 186 gives via the intermediate 189 the pyrano-fused oxazine 190 with hydroxylamine, pyridazines 191 and 192 respectively with hydrazine and phenylhydrazine (Scheme 28). ${ }^{93}$

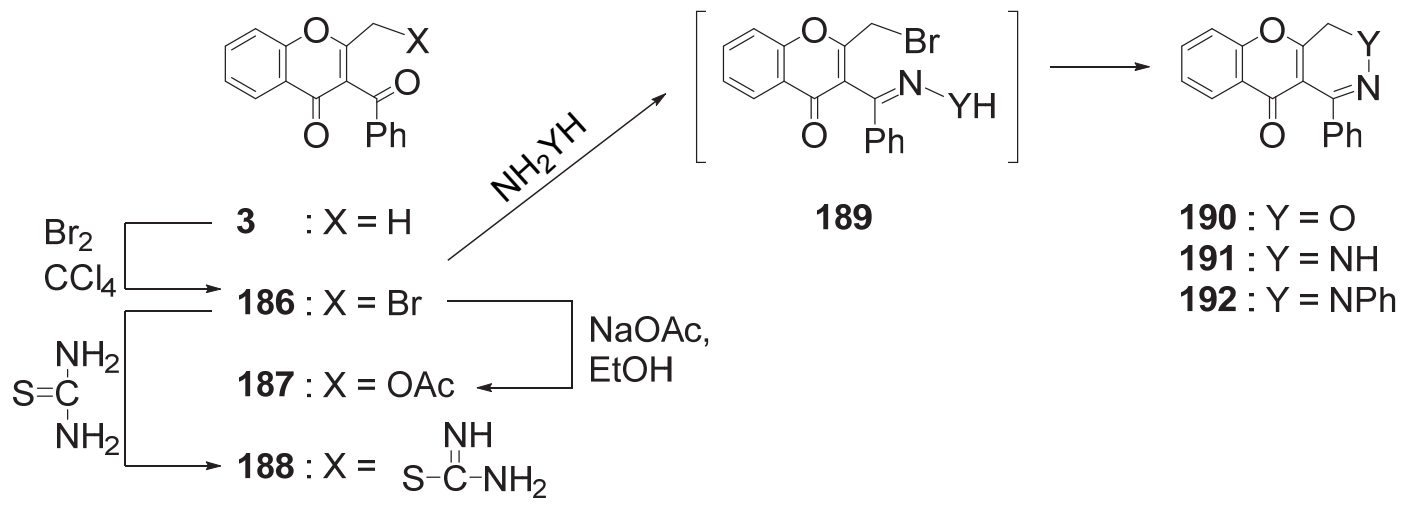

\section{Scheme 28}

Thiourea brings about substitution reaction in 186 giving 188 (Scheme 28) that survives heating under reflux even in a high boiling solvent such as ethylene glycol. In contrast, a mixture 
of 186 and thioacetamide on being heated under reflux in ethanol containing AcONa produces the thieno[3,4-b][1]benzopyranone 195. Here the intermediate 193, initially resulting from substitution of bromine by thioacetamide, undergoes base catalyzed acetonitrile eliminative cyclization (to 194) and subsequent water elimination to 195 (Scheme 29). ${ }^{93}$

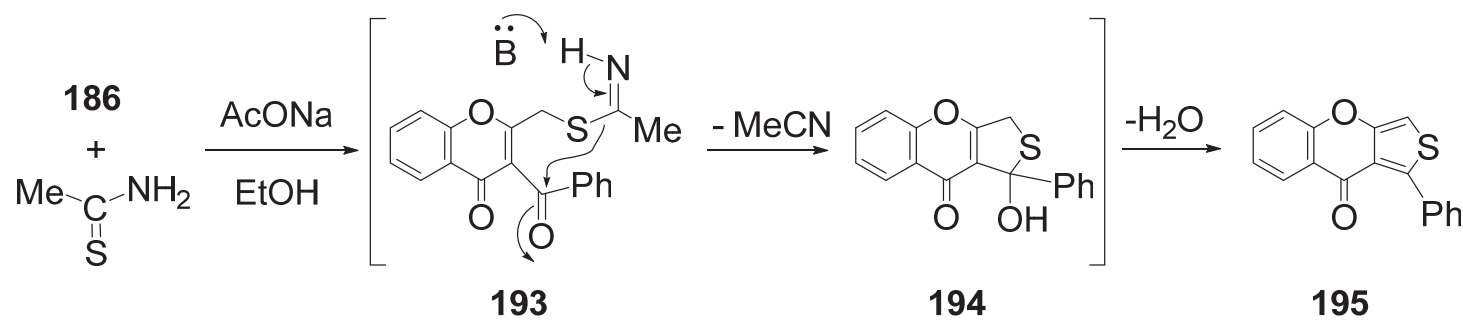

\section{Scheme 29}

A Russian group ${ }^{94}$ has treated the chromone 3 with 2.2 equivalents of bromine to obtain 3 benzoyl-2-(dibromomethyl)chromone 196 that condenses with thioacetamide to give the thienochromone 195, instead of the normally expected bromothiophene 197 (Scheme 30); the formation of $\mathbf{1 9 5}$ is not rationalized.

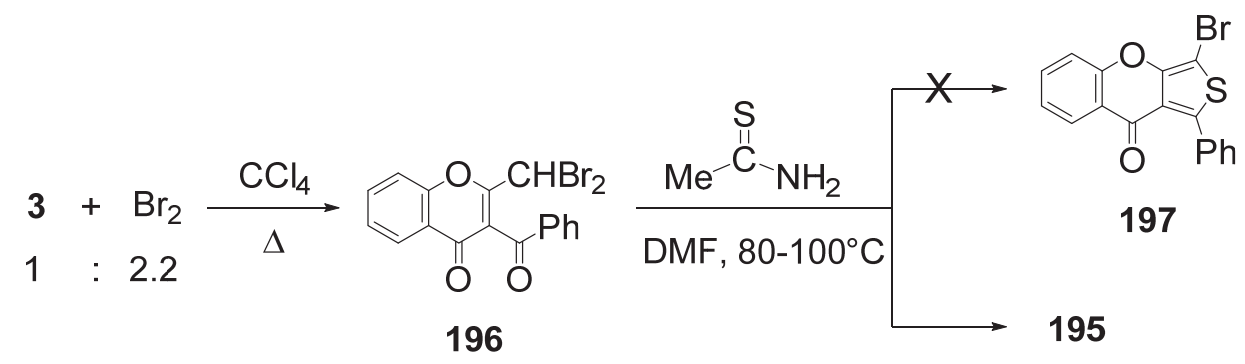

\section{Scheme 30}

\section{Benzopyrans 1-5 as Nucleophiles}

The 2-methyl group of the chromones 1-5, being vinylogous to two carbonyl groups, functions as a nucleophilic centre even under weakly basic conditions so as to undergo addition to various electrophilic compounds as described in the following subsections.

\subsection{Addition to the carbonyl compounds}

The ester 5a condenses with cyclohexanone 198 in the presence of $t$-butoxide in butanol/dimethoxyethane giving the spirolactone 199; it in polar media exists in equilibrium with the acid 200 so that its treatment with diazomethane in diethyl ether leads to the cyclohexylidene ester $\mathbf{2 0 1}$ cyclizable by polyphosphoric acid to the tetrahydrobenzoxanthone 202 (Scheme 31 ). ${ }^{95}$ 


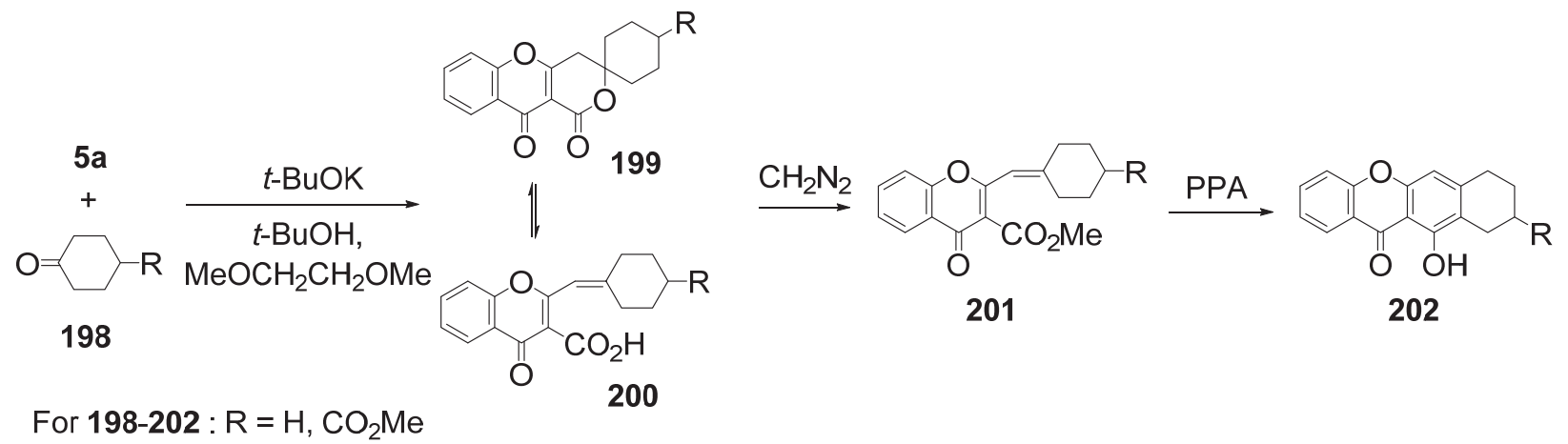

\section{Scheme 31}

3-Formylchromone 6a functions as an aromatic aldehyde to condense with 3-acetyl-2methylchromone 2 in $\mathrm{Ac}_{2} \mathrm{O}$-AcONa giving the 2-ethenylchromone 203 (Equation 13). ${ }^{35}$ This mode of addition differs from the one described in the following subsection.

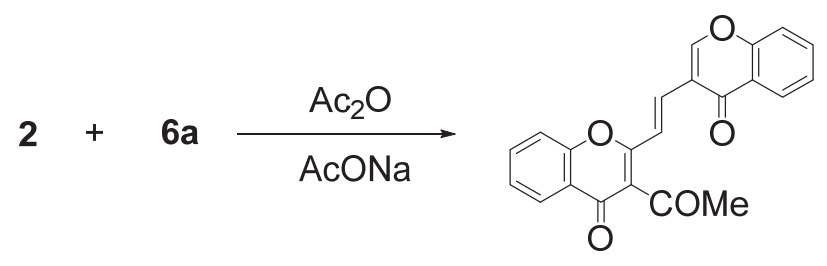

\subsection{Addition to unsaturated carbonyl compounds}

3-Acetylchromone $\mathbf{6 b}$ dissolved in ethanol or dioxane on treatment with triethylamine or pyridine at room temperature or by percolation through Brockmann neutral alumina affords, without acid treatment, the xanthone 204. Here $\mathbf{6 b}$ undergoes acyl-acyl rearrangement under base catalysis to 1 and condensation between these two chromone derivatives leads to the xanthone 204. ${ }^{14}$ Again the aldehyde 1 on treatment with alumina also affords the xanthone $204 .{ }^{96}$ The formation of $\mathbf{2 0 4}$ may be rationalized in the following way. Alumina (alumina lattice oxide anion, represented by $\mathrm{LO}^{-}$) catalyzed isomerization of $\mathbf{1}$ to $\mathbf{6} \mathbf{b}$ and a subsequent Michael initiated ring closure between $\mathbf{1}$ and $\mathbf{6 b}$ leads to the intermediate 203 that on base catalyzed deacylative hydroxy elimination and pyran ring opening (or deacylative pyran ring opening and water elimination) gives 204 (Scheme 32). ${ }^{96}$ 


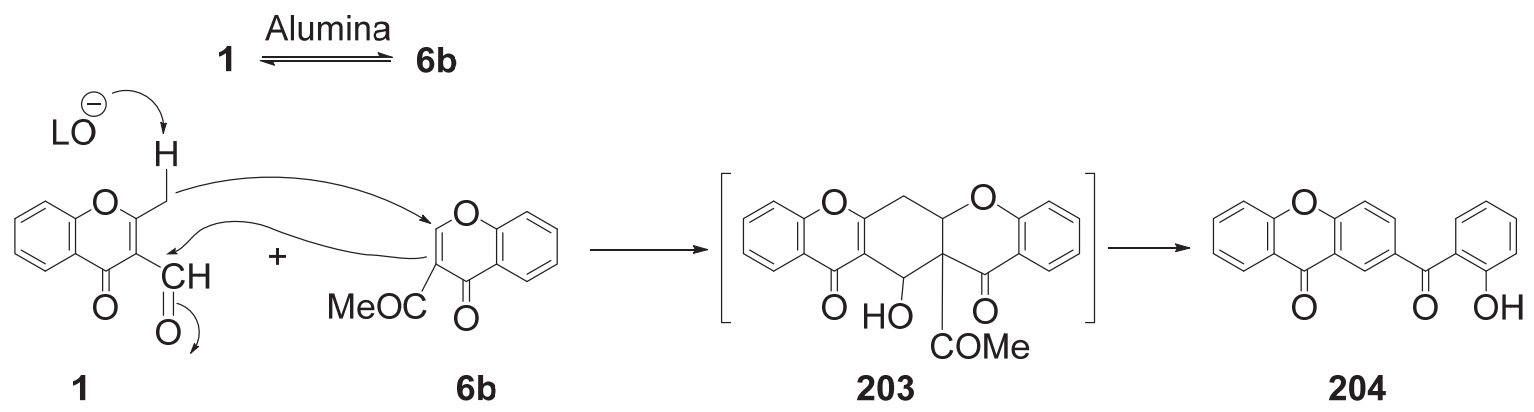

\section{Scheme 32}

Interestingly, when a mixture of the aldehyde $\mathbf{1}$ or the corresponding hydrazone $\mathbf{2 4}$ and any of the chromones $\mathbf{6 a , b , d}$ is heated in dioxane in the absence of any catalyst, the xanthone $\mathbf{2 0 4}$ also results. Here $\mathbf{1}$ as well as $\mathbf{2 4}$ tautomerizes to $\mathbf{2 0 5}$ that having an $o$-quinodimethane structure undergoes a facile Diels-Alder reaction with the pyranodienophiles; the resultant adduct 206 gives 204 by an elimination process (Scheme 33). ${ }^{14}$

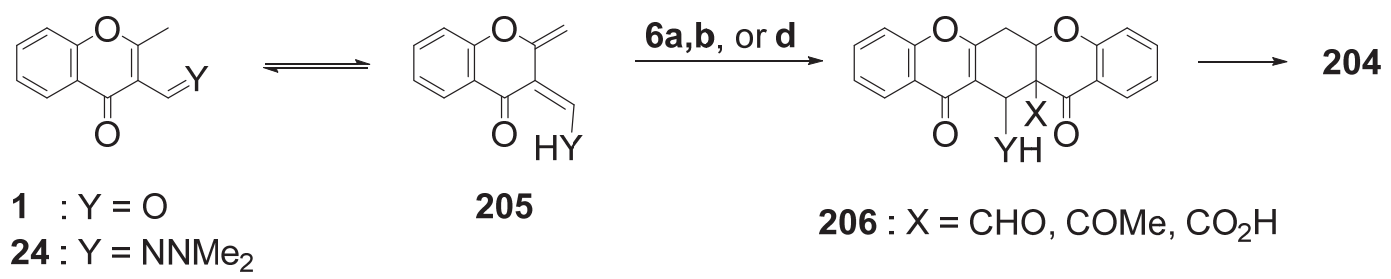

\section{Scheme 33}

Pyridine-piperidine, unlike alumina, brings about self-condensation of the aldehyde 1 to the xanthone 207 and pulverized sodium converts the ketone 2 into xanthone $208 .{ }^{97}$ The 2methylchromone $\mathbf{2}$ in the presence of NaOMe undergoes Michael addition to 3-acetyl-2(methylthio)chromone 209 followed by expulsion of thiomethanol to give the 2-(1-benzopyran2-yl)methylene-1-benzopyran 210; the later is accompanied by a small amount of 3-acetyl-4hydroxycoumarin formed by base catalyzed hydrolysis of the unreacted chromone 209 . $^{97}$

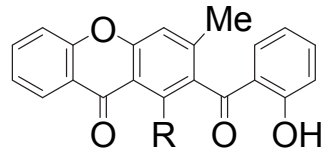

$207: \mathrm{R}=\mathrm{H}$

$208: \mathrm{R}=\mathrm{Me}$

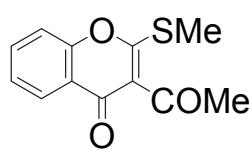

209

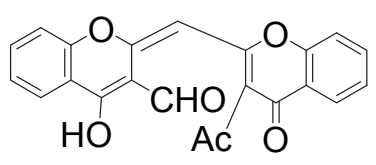

210

Gong et al. ${ }^{98}$ have studied the DBU-catalyzed reactions of the aldehyde $\mathbf{1}$, ketone $\mathbf{2}$ and ester 5b with 3-(2-acylethenyl)chromone 211. The carbanion generated from the 2-methyl group 
of aforesaid chromone substrates undergoes under DBU catalysis domino 1,6-addition to the $\alpha, \beta, \gamma, \delta$-unsaturated ketone functionality of $\mathbf{2 1 1}$ - intramolecular Michael addition to the 2methylchromone moiety - pyran ring opening to give the intermediate 212; the new six membered ring in $\mathbf{2 1 2}$ formed due to this [4+2]cyclization aromatizes to $\mathbf{2 1 3}$ by pyran ring opening and a 1,3-H shift. The intermediate $213(\mathrm{R}=\mathrm{Me})$ arising from $\mathbf{2}$ and $\mathbf{2 1 1}$ cyclizes to the xanthone 214, that $(213, \mathrm{R}=\mathrm{H})$ from 1 and $211\left(\mathrm{R}^{1}=4-\mathrm{O}_{2} \mathrm{~N}-\mathrm{C}_{6} \mathrm{H}_{4}\right)$ cyclizes to 215 , and the ketone-ester $213\left(\mathrm{R}=\mathrm{OEt} ; \mathrm{R}^{1}=4-\mathrm{O}_{2} \mathrm{~N}-\mathrm{C}_{6} \mathrm{H}_{4}\right)$ yields the 3-aryl-4-hydroxycoumarin 216 (Scheme 34).

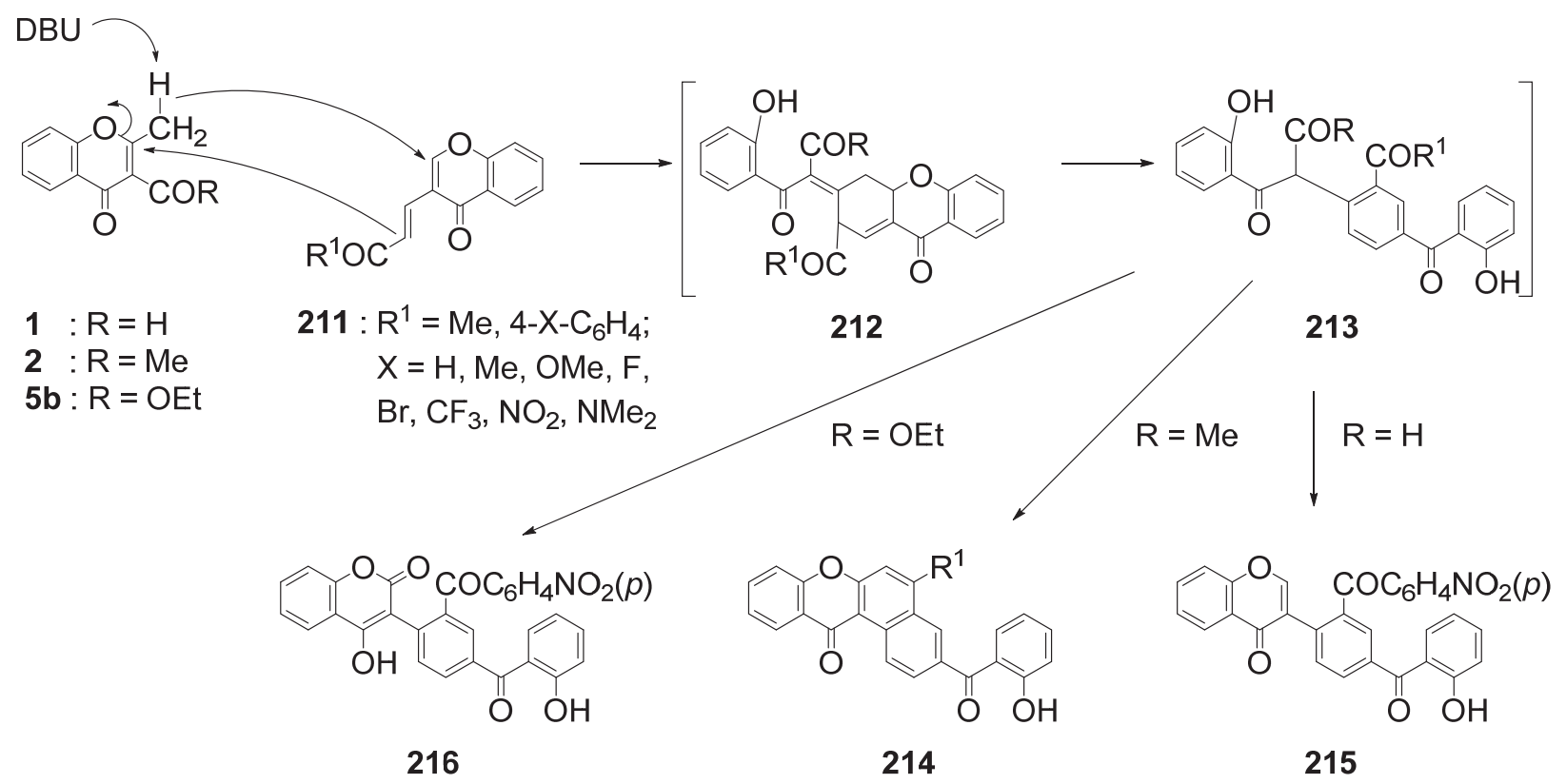

\section{Scheme 34}

3-Alkenylchromone $\mathbf{2 1 7}$ behaves similarly to $\mathbf{2 1 1}$ towards 3-acetyl-2-methylchromone $\mathbf{2}$, to give via 218 the 3-aryl-2-methylchromone 219 (Scheme 35). ${ }^{98}$

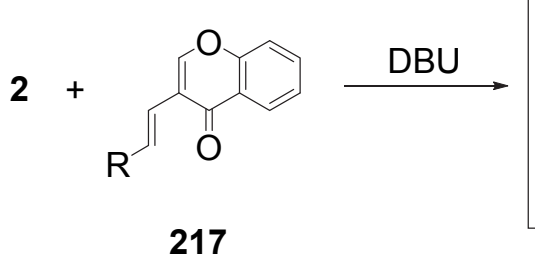

217

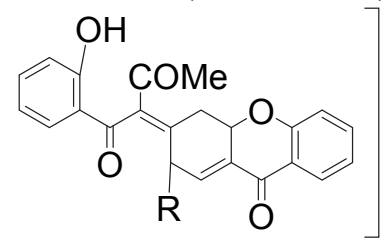

218<smiles>[R]c1cc(C(=O)c2ccccc2O)ccc1C1C(=O)c2ccccc2OC1C</smiles>

219

For 217-219: $\mathrm{R}=\mathrm{CO}_{2} \mathrm{Et}, \mathrm{CN}, \mathrm{Ph}, 4-\mathrm{MeOC}_{6} \mathrm{H}_{4}, 4-\mathrm{O}_{2} \mathrm{NC}_{6} \mathrm{H}_{4}$

\section{Scheme 35}




\section{Aminomethylenation of 2-Methylchromones 1 -5: Reactions of 2-(2-Dimethylaminoethenyl)chromones}

Methylenation of 2-methylchromones $\mathbf{1 - 5}$ by $N, N$-dimethylformamide dimethyl acetal leads to the corresponding trans-enamines 220a-e, respectively, ${ }^{97,99-101}$ the cisoid or transoid conformation of its diene system not being established. The chromone $220 \mathrm{~b}$ on being heated in DMF or with $\mathrm{NaOMe}$ in $\mathrm{MeOH}$ undergoes [6+0] cyclization with expulsion of the $\mathrm{NHMe}_{2}$ giving 1-hydroxyxanthone 221. ${ }^{101} \mathrm{DMF}^{-\mathrm{POCl}_{3}}$ converts $\mathbf{2 2 0 b}$ into 1-chloro-4-formylxanthone 222. ${ }^{97}$

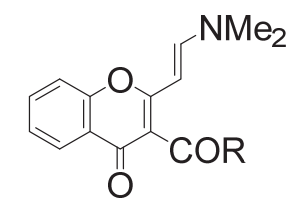

220 a : $\mathrm{R}=\mathrm{H}$

b : $R=M e$

c: $: \mathrm{R}=\mathrm{Ph}$

d: $\mathrm{R}=\mathrm{OH}$

e : $\mathrm{R}=\mathrm{OMe}$ or OEt

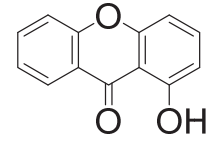

221

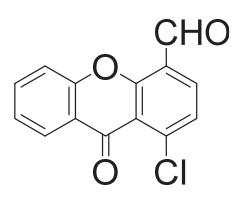

222

A nitrogen nucleophile of the general formula $\mathrm{NH}_{2} \mathrm{YH}$ brings about transamination of the enamine 220 via a 1,6-addition - elimination sequence and the resultant enamine, due to prototropy, assumes a stereochemical configuration (cisoid diene with cis geometry around the exocyclic olefinic bond) as shown in the intermediate chromone 223; the latter takes different reaction courses depending on the nature of its NHYH group. Thus, the enamine $220(\mathrm{R}=\mathrm{H}$, $\mathrm{Me}, \mathrm{Ph}$ ) gives the fused pyridine 224 with ammonia via the intermediate 223 ( $\mathrm{Y}=$ bond). The compound 220a gives intractable tar with hydrazine whereas the other two members $\mathbf{2 2 0 b}, \mathbf{c}$ give the pyrazoles 225 and 226 respectively with hydrazine and phenylhydrazine via 223 (Y $=\mathrm{NH}$, $\mathrm{NPh}$ ). Guanidine, acethydrazide and hydroxylamine convert $\mathbf{2 2 0}$ into the pyrimidine 227, pyridine $N$-acetylimide $\mathbf{2 2 8}$ and pyridine $N$-oxide $\mathbf{2 2 9}$ via the corresponding intermediate 223, respectively. The compound $\mathbf{2 2 8}$ on being refluxed in ethylene glycol thermolyses to the pyridine 224 (Scheme 36). ${ }^{99}$

When refluxed with glycine ester hydrochloride in ethanol-pyridine, the enamines $\mathbf{2 2 0 b}$ and 220c give the enamino esters 230 b and 230c, respectively. The substituted glycine ester 230 on being refluxed in ethanol-sodium ethoxide followed by acid treatment gives the azepine 232, presumably by hydrolysis and subsequent decarboxylation of the [7+0] cyclization product 231 of 230 (Scheme 37). ${ }^{99}$ 


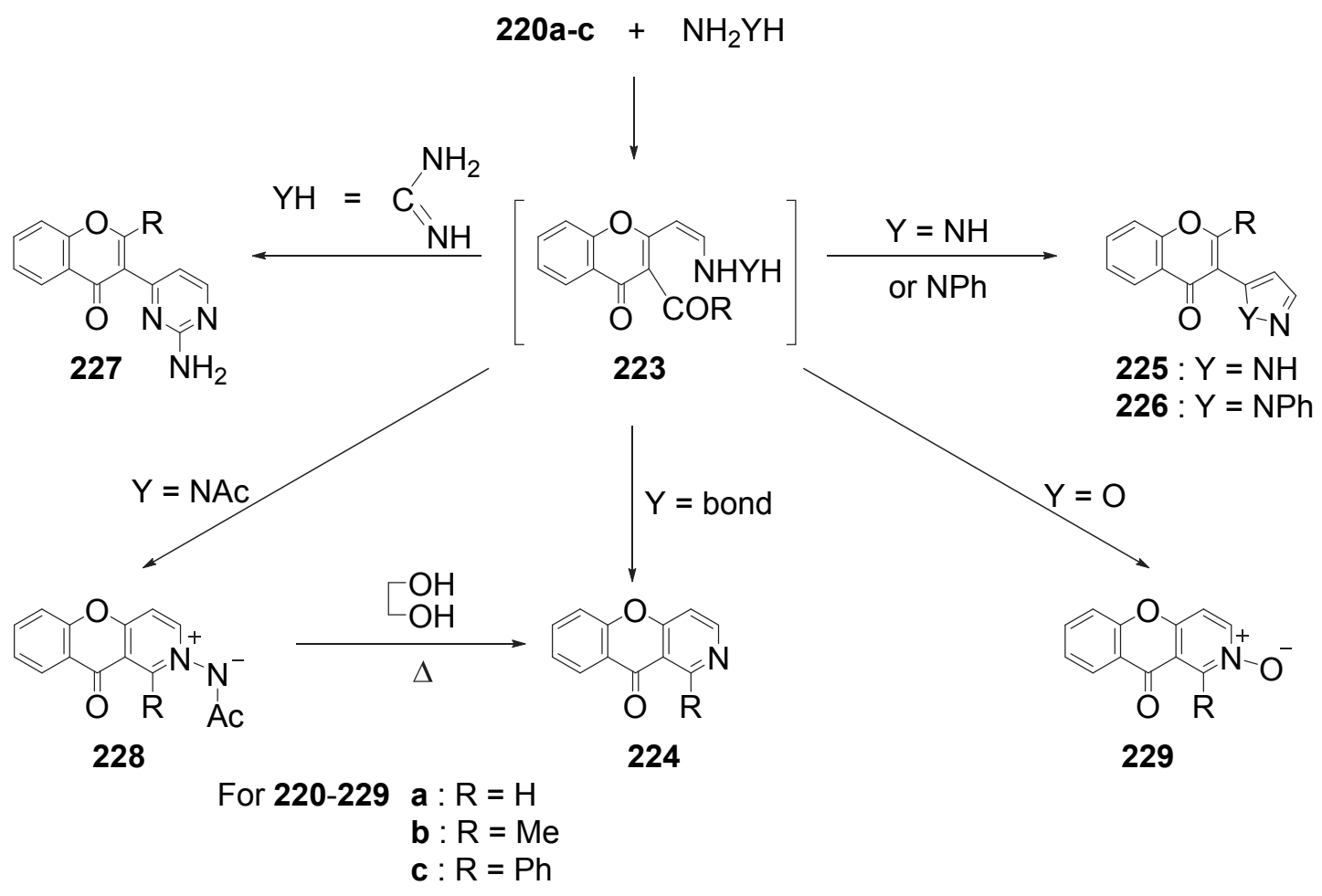

Scheme 36

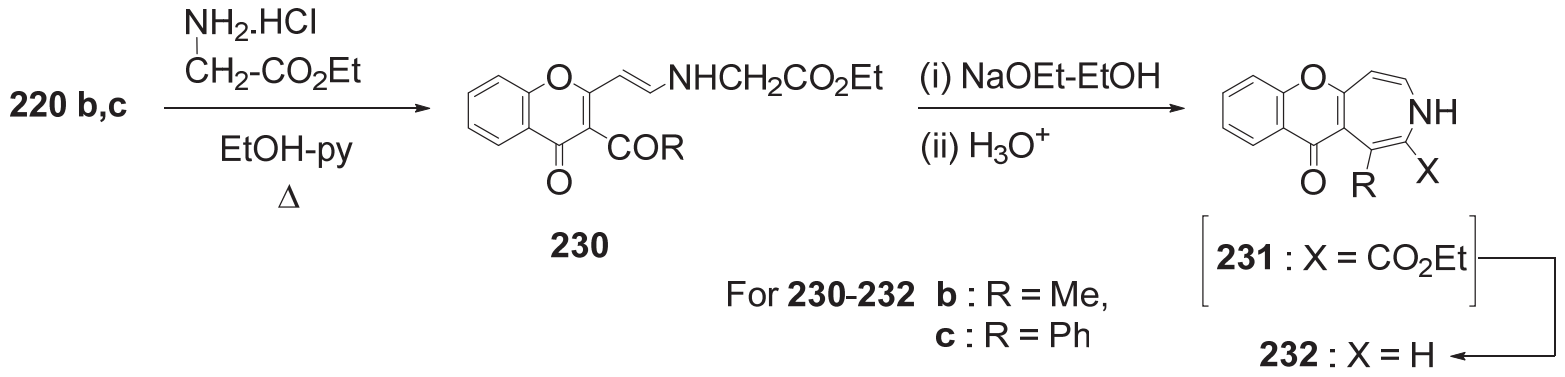

\section{Scheme 37}

A mixture of the enamino-acid 220d, $\mathrm{NH}_{2} \mathrm{OH} . \mathrm{HCl}$ and $\mathrm{NaOAc}$ in refluxing ethanol affords chromone-2-acetonitrile $\mathbf{2 3 6}$ by a mechanism as shown in Scheme 38. The intermediate 223 resulting from transamination of $220 d$ by $\mathrm{NH}_{2} \mathrm{OH}$ undergoes intramolecular 1,4-addition; the resultant spiro-compound $\mathbf{2 3 4}$ by decarboxylative isoxazoline ring opening followed by a 1,3hydrogen shift gives the oxime $\mathbf{2 3 5}$ that is dehydrated under reaction conditions to the nitrile 236. ${ }^{100}$ 


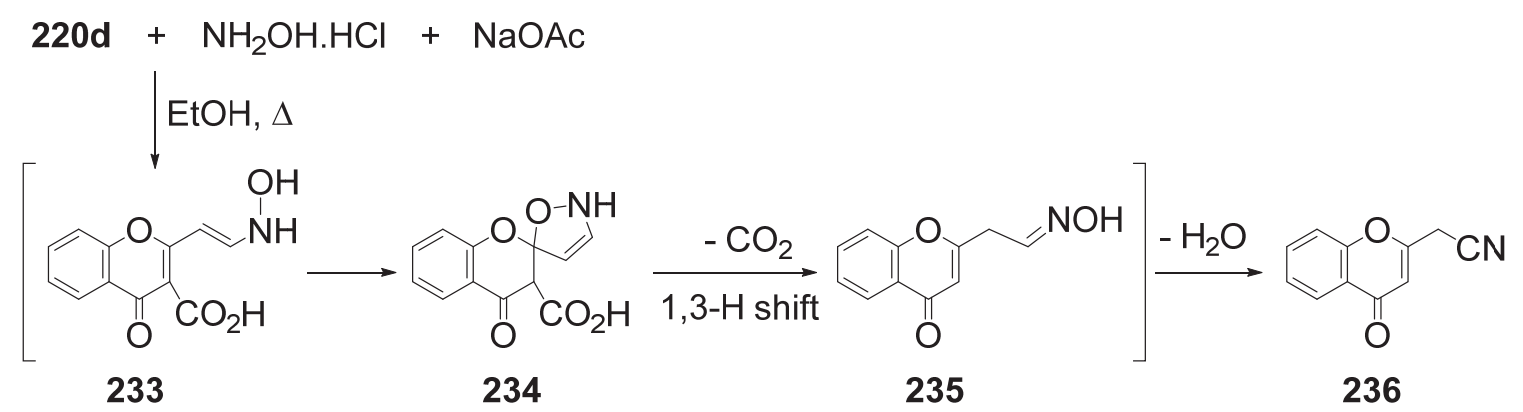

\section{Scheme 38}

The ester 220e $(\mathrm{R}=\mathrm{OMe})$ gives 1 -benzopyranopyridine $N$-oxide 237 with hydroxylamine, benzopyranopyridine $N$-acetylimide 238 with acethydrazide and coumarin-3-ylpyrazole 239 with phenylhydrazine. $^{100}$

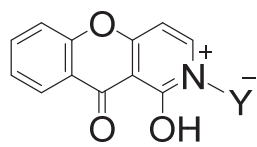

$237: Y=O$

$238: Y=N A C$

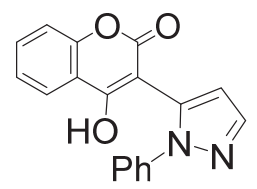

239

The dienaminoketone 220b when heated with DMAD (240a) in DMF gives a mixture of the xanthone dicarboxylates $\mathbf{2 4 4}$ and 249 admixed with a small amount ( $\sim 5 \%)$ of 1-hydroxyxanthone 221 whereas 220c under similar conditions gives exclusively the xanthone 250. Here the diene 220 behaves as an unconjugated enamine in undergoing [2+2] cycloaddition with the electron deficient acetylene 240 to give the adduct 241 (Scheme 39). ${ }^{101}$ The cyclobutene moiety in 241 having both an electron acceptor and an electron donor substituents in appropriate disposition undergoes symmetry allowed ring opening to $\mathbf{2 4 2}$ that takes different reaction courses dependent on the nature of its $\mathrm{R}, \mathrm{Y}$ and $\mathrm{E}$ groups. Electrocyclization of $242\left(\mathrm{R}=\mathrm{Me}, \mathrm{Y}=\mathrm{E}=\mathrm{CO}_{2} \mathrm{Me}\right)$ to 243 followed by base catalyzed deacylative deamination gives the xanthone 244, 243 itself functioning as the base (path $a$ ). The zwitterion 247 formed from $242\left(\mathrm{R}=\mathrm{Me}, \mathrm{Y}=\mathrm{E}=\mathrm{CO}_{2} \mathrm{Me}\right)$ by intramolecular 1,2-addition of enamine to the carbonyl group cyclizes to the oxetane $\mathbf{2 4 8}$ that undergoes thermal cycloreversion to the xanthone 249 (path $b$ ). In the reaction of 220c with 240a, the base catalyzed debenzoylation of the intermediate $243\left(\mathrm{R}=\mathrm{Ph}, \mathrm{Y}=\mathrm{E}=\mathrm{CO}_{2} \mathrm{Me}\right)$ is not possible. So the intermediate $242\left(\mathrm{R}=\mathrm{Ph}, \mathrm{Y}=\mathrm{E}=\mathrm{CO}_{2} \mathrm{Me}\right)$ follows the reaction path $b$ to give the xanthone $\mathbf{2 5 0}$.

The dienaminoketone $220 \mathrm{~b}$ is converted into 245 by dibenzoylacetone $(\mathbf{2 4 0 b})$, and a mixture of xanthone 246 and flavone 253 by ethyl propiolate (240c). The former two products (245 and 246) arise through the intermediates $243(\mathrm{R}=\mathrm{Me}, \mathrm{Y}=\mathrm{E}=\mathrm{COPh})$ and $243(\mathrm{R}=\mathrm{Me}, \mathrm{Y}$ $\left.=\mathrm{H}, \mathrm{E}=\mathrm{CO}_{2} \mathrm{Et}\right)$ (path $\left.a\right)$, respectively. The enamine $242\left(\mathrm{R}=\mathrm{Me}, \mathrm{Y}=\mathrm{H}, \mathrm{E}=\mathrm{CO}_{2} \mathrm{Et}\right)$ arising from 220b and 240c undergoes [2+2]cycloaddition with a second molecule of ethyl propiolate, 
the resultant cyclobutene intermediate $\mathbf{2 5 1}$ by ring opening (to 252) and recyclization giving the flavone 253 (path $c$ ).

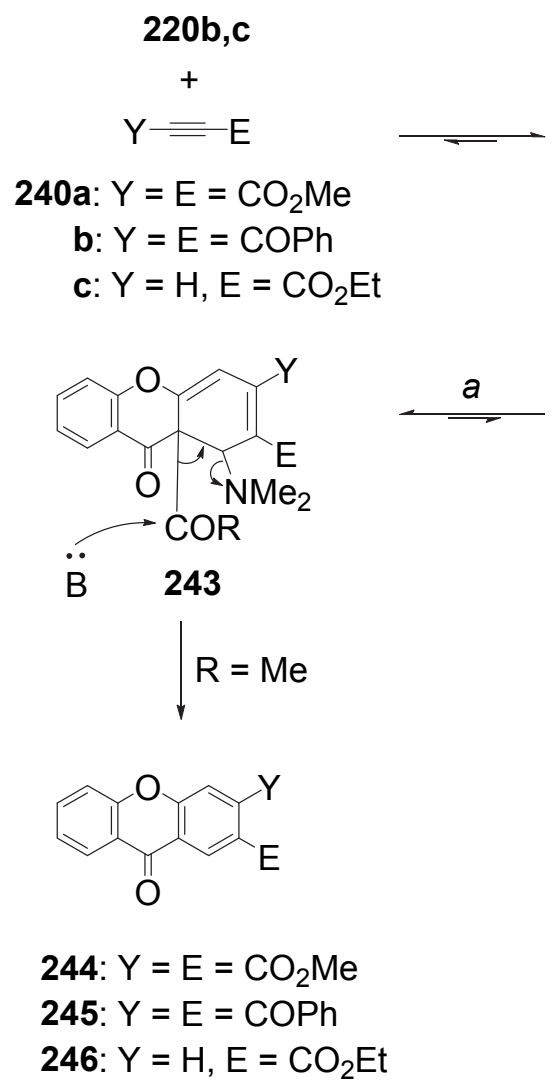

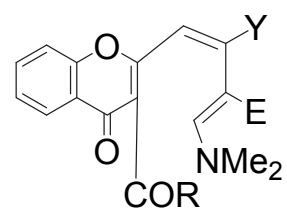

242

$b \| \mathrm{R}=\mathrm{Me}, \mathrm{Ph}$

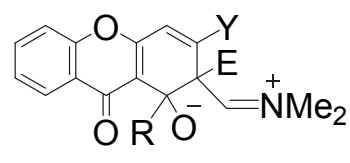

247

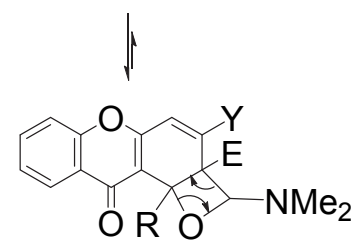

248

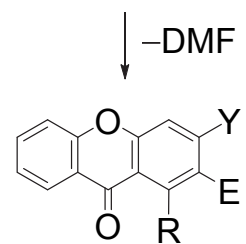

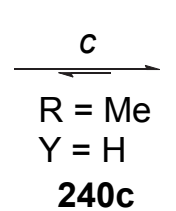

240c<smiles>CC(C)(C)c1c(/C=C/C2(F)CC(F)CC2F)oc2ccccc2c1=O</smiles>

251

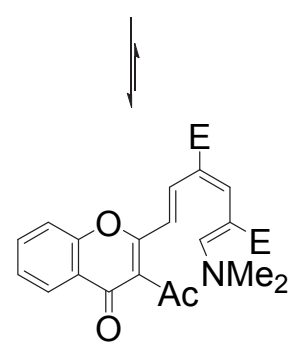

252

$-\mathrm{NHMe}_{2}$<smiles>CCOC(=O)c1cc(C(=O)OCC)cc(-c2oc3ccccc3c(=O)c2C(C)(C)C)c1</smiles>

249: $\mathrm{R}=\mathrm{Me}, \mathrm{Y}=\mathrm{E}=\mathrm{CO}_{2} \mathrm{Me}$

250: $\mathrm{R}=\mathrm{Ph}, \mathrm{Y}=\mathrm{E}=\mathrm{CO}_{2} \mathrm{Me}$

\section{Scheme 39}

\section{3-Acetyl-2-methylchromone as a Ligand in Mixed Ligand Metal Complexes}

An Indian group ${ }^{102-104}$ have prepared novel six coordinated dimeric Fe(III) as well as five coordinated dimeric $\mathrm{Fe}$ (II) and $\mathrm{Cu}$ (II) complexes with 3-acetyl-7-ethoxy-2-methylchromone 254 as one ligand (L) along with two other ligands, namely 7-chloro-1-cyclopropyl-6-fluoro-4-oxo1,4-dihydroquinoline-3-carboxylic acid 255 and piperazine 256 (abbreviated respectively as cip 
and pip); the last named two ligands are obtained by splitting ciprofloxacin hydrochloride (cpf.HCl) 257 with alkali. This ligand mixture gives $\left[\mathrm{Fe}_{2} \mathrm{~L}_{2}(\mathrm{cip})_{2}(\mathrm{OH})_{2}(\right.$ pip) $] .5 \mathrm{H}_{2} \mathrm{O}$ with ferric nitrate in the presence of alkali, ${ }^{102}\left[\mathrm{Fe}_{2} \mathrm{~L}_{2}(\mathrm{cip})_{2}(\right.$ pip) $] .5 \mathrm{H}_{2} \mathrm{O}$ with ferrous sulfate ${ }^{103}$ and $\left[\mathrm{Cu}_{2} \mathrm{~L}_{2} \text { (cip) }\right)_{2}$ (pip)].5 $\mathrm{H}_{2} \mathrm{O}$ with cupric nitrate ${ }^{104}$ having respectively the octahedral, distorted square pyramidal and square pyramidal geometry. Each metal in these complexes is coordinated to the deprotonated carboxylate oxygen and pyridine oxygen of cip, two carbonyl oxygens of chromone ligand $\mathrm{L}$ and one nitrogen of piperazine. Piperazine by coordination through its second nitrogen to the other metallic centre tethers two metal centres in the said dimeric complexes. The ferric ion in $\mathrm{Fe}$ (III) complex is additionally bonded to one hydroxyl anion. DNA binding activity as well as biological activities against several gram-positive and gram-negative bacterial cultures of the metal complexes have been assessed.<smiles>CCOc1ccc2c(=O)c(C(C)=O)c(C)oc2c1</smiles>

$254 \equiv \mathrm{L}$

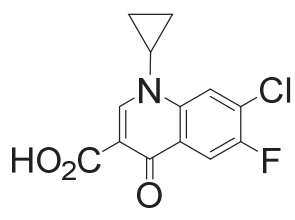

255<smiles>C1CNCCN1</smiles>

256<smiles>O=C(O)c1cn(C2CC2)c2cc(N3CCNCC3)c(F)cc2c1=O</smiles>

257

\section{Conclusions}

Syntheses of all the members 1-5 belonging to the title chromone family and their various reactions as electrophilic as well as nucleophilic substrates studied during the last thirtyfive years have been comprehended.

\section{References}

1. Ghosh, C. K. J. Heterocycl. Chem. 2006, 43, 813-820.

http://dx.doi.org/10.1002/jhet.5570430401

2. Sosnovskikh, V. Y.; Moskin, V. S. Chem. Heterocycl. Comp. 2012, 48, 139-146. http://dx.doi.org/10.1007/s10593-012-0977-3

3. Ghosh, C. K.; Chakraborty, A. Arkivoc 2015, (vi), 417-445. http://dx.doi.org/10.3998/ark.5550190.p009.273

4. Ibrahim, M. A.; El-Sayed Ali, T.; El-Gohary, N. M.; El-Kazak, A. M. Eur. J. Chem. 2013, 4, 311-318.

http://dx.doi.org/10.5155/eurjchem.4.3.311-328.815

5. Sepay, N.; Dey, S. P. J. Heterocycl. Chem. 2014, 51, E1-E24.

http://dx.doi.org/ 10.1002/jhet.2001

6. Ghosh, C. K.; Chakraborty, A. Arkivoc, 2015, (vi), 288-361.

http://dx.doi.org/10.3998/ark.5550190.p009.020

7. Schneider, W.; Kunau, F. Ber. Deut. Chem. Ges. 1921, 54B, 2302-2310. 
http://dx.doi.org/10.1002/cber.19210540920

8. Badawy, D. S.; Kandeel, E. M.; Awad, N. M.; Abdel-Rahman, A.-R. H. Phosphorus, Sulfur Silicon Relat. Elem. 2009, 184, 179-196.

http://dx.doi.org/10.1080/10426500802083158

9. Abdel-Rahman, A.-R. H.; Keshk, E. M.; El-Telbani, E. M. Z. Naturforsch 2002, 57B, 557562.

http://www.znaturforsch.com/ab/v57b/s57b0557.pdf

10. Buggy, T.; Ellis, G. P. J. Chem. Res. (S) 1980, 159; J. Chem. Res. (M) 1980, 2314-2324.

11. Clarke, P. D.; Fitton, A. O.; Suschitzky, H.; Wallace, H. T. W.; Dowlatshahi, H. A.; Suschitzky, J. L. Tetrahedron Lett. 1986, 27, 91-94.

http://dx.doi.org/10.1016/S0040-4039(00)83949-0

12. Ghosh, C. K.; Biswas, S.; Bhattacharya, A.; Sasmal, N. J. Chem. Res. (S) 1990, 117.

13. Ghosh, C. K.; Biswas, S. J. Indian Chem. Soc. 1990, 67, 568-570.

14. Ghosh, C. K.; Bhattacharya, A.; Bandyopadhyay, C. J. Chem. Soc., Chem. Commun. 1984, 1319-1320.

http://dx.doi.org/10.1039/C39840001319

15. Ganguly, A. K.; Kaur, S.; Mahata, P. K.; Biswas, D.; Pramanik, B. N.; Chan, T. M. Tetrahedron Lett. 2005, 46, 4119-4121.

http://dx.doi.org/10.1016/j.tetlet.2005.04.010

16. Jain. A. C.; Arya, P.; Nayyar, N. K. Indian J. Chem. 1984, 23B, 1030-1035.

17. Jain, A. C.; Bambah, P. K. Proc. Indian Nat. Sci. Acad. 1987, 53A, 564-575.

18. Jain, A. C.; Tyagi, O. D.; Gupta, A. Indian J. Chem. 1986, 25B, 755-758.

19. Jain, A. C.; Nayyar, N. K.; Srivastava, R. Indian J. Chem. 1985, 24B, 1023-1031.

20. Vandana, T.; Prasad, K. J. R.; Sowmithran, D. Indian J. Chem. 2004, 43B, 2405-2409. http://nopr.niscair.res.in/handle/123456789/21374

21. Iyer, P. R.; Iyer, C. S. R.; Prasad, K. J. R. Indian J. Chem. 1983, 22B, 1055-1056.

22. Prasad, K. J. R.; Vijaylakshmi, C. S.; Magundeswaran, P. N.; Subramaniam, E. P.; Shanmugam, P. Indian J. Chem. 1988, 27B, 475-477.

23. Ghate, M.; Kulkarni, M. V. Indian J. Chem. 2005, 44B, 1674-1678. http://nopr.niscair.res.in/handle/123456789/9154

24. Ghate, M.; Kusanur, R. A.; Kulkarni, M. V. Eur. J. Med. Chem. 2005, 40, 882-887. http://dx.doi.org/10.1016/j.ejmech.2005.03.025

25. Copeland, R. J.; Hill, R. A.; Hinchacliffe, D. J.; Staunton, J. J. Chem. Soc., Perkin Trans. 1 1984, 1013-1019.

http://dx.doi.org/10.1039/P19840001013

26. Gueye, R.; Poguet, C.; Champavier, Y.; Buxeraud, J.; Duroux, J.-L.; Fagnere, C. Compt. Rend. Chim. 2014, 17, 443-449.

http://dx.doi.org/10.1016/j.crci.2013.10.004

27. Chanda, T.; Chowdhury, S.; Koley, S.; Anand, N.; Singh, M. S. Org. Biomol. Chem. 2014, 12, 9216-9222. 


\section{http://dx.doi.org/10.1039/C4OB01743A}

28. Baldovi, V.; Corma, A.; Garcia, H.; Iborra, S.; Miranda, M. A.; Primo, J. Recl. Trav. Chim. Pays-Bas 1992, 111, 126-128. http://dx.doi.org/10.1002/recl.19921110303

29. Rohan, D.; Canaff, C.; Fromentin, E.; Guisnet, M. J. Catalysis 1998, 177, 296-305. http://dx.doi.org/10.1006/jcat.1998.2108

30. Miky, J. A. A.; Sharaf, H. H. Indian J. Chem. 1998, 37B, 68-72.

31. Dean, F. M.; Johnson, R. S. J. Chem. Soc., Perkin Trans 1 1981, 224-230. http://dx.doi.org/10.1039/P19810000224

32. Ghosh, C. K.; Bhattacharyya, A.; Ghosh-Dastidar, P. P. Indian J. Chem. 1987, 26B, 128130.

33. Kelly, T. R.; Kim, M. H. J. Org. Chem. 1992, 57, 1593-1597. http://dx.doi.org/10.1021/jo00031a049

34. Ding, K.; Wang, S. Tetrahedron Lett. 2005, 46, 3707-3709. http://dx.doi.org/10.1016/j.tetlet.2005.03.143

35. Lacova, M.; El-Shaaer, H. M.; Loos, D.; Matulova, M.; Chovanocva, J.; Furdik, M. Molecules 1998, 3, 120-131. http://dx.doi.org/10.3390/30300120

36. Clarke, D. S.; Gabbut, C. D.; Hepworth, J. D.; Heron, B. M. Tetrahedron Lett. 2005, 46, 5515-5519. http://dx.doi.org/10.1016/j.tetlet.2005.06.058

37. Bondge, S. P.; Mahalle, S. R.; Burungale, A. S.; Patil, L. R.; Mane, R. A. Indian J. Chem. 2009, 48B, 1435-1437. http://nopr.niscair.res.in/handle/123456789/6107

38. Gadaginamath, G. S.; Kavali, R. R. Indian J. Chem. 1999, 38B, 178-182. http://nopr.niscair.res.in/handle/123456789/16204

39. Eiden, F.; Schuenemann, J. Arch. Pharm (Weinheim) 1983, 316, 201-209. http://dx.doi.org/10.1002/ardp.19833160304

40. Ali, S. M.; Ilyas, M. J. Chem. Res(s). 1987, 52-53.

41. Yu, Y.; Hu, Y.; Shao, W.; Huang, J.; Zuo, Y.; Huo, Y.; An, L.; Du, J.; Bu, X. Eur. J. Org. Chem. 2011, 24, 4551-4563.

http://dx.doi.org/10.1002/ejoc.201100435

42. Costa, A. M. B. S. R. C. S.; Dean, F. M.; Jones, M. A.; Smith, D. A. J. Chem. Soc., Perkin Trans 1 1986, 1707-1712. http://dx.doi.org/10.1039/P19860001707

43. Jung, J.-C.; Min, J.-P.; Park, O.-S. Synth. Commun. 2001, 31, 1837-1845. http://dx.doi.org/10.1081/SCC-100104333

44. Charlton, J. L.; Lypka, G.; Sayeed, V. J. Heterocycl. Chem. 1980, 17, 593-594. http://dx.doi.org/10.1002/jhet.5570170335

45. Babin, P.; Dunogues, J.; Petraud, M. Tetrahedron 1981, 37, 1131-1139. 
http://dx.doi.org/10.1016/S0040-4020(01)92042-3

46. Kim, H. J. Korean Chem. Soc. 1996, 40, 549-556.

http://newjournal.kcsnet.or.kr/main/__search/j_abstract view.htm?code=K960803\&qpage= j_search\&spage $=$ b_jkcs\&dpage $=$ ar

47. Coppola, G. M.; Dodsworth, R. W. Synthesis 1981, 523-524.

http://dx.doi.org/10.1055/s-1981-29508

48. Saloutin, V. I.; Bazyĺ, I. T.; Skryabina, Z. E.; Kisil', S. P. Russ. J. Org. Chem. 1997, 33, 1167-1175.

49. Kisil', S. P.; Burgart, Y. V.; Saloutin, V. I.; Chupakhin, O. N. J. Fluorine Chem. 2001, 108, 125-131.

http://dx.doi.org/10.1016/S0022-1139(01)00346-3

50. Burgart, Y. V.; Kisil', S. P.; Saloutin, V. I.; Chupakhin, O. N. Mendeleev Commun. 2001, 76-76.

http://pubs.rsc.org/en/Content/ArticleLanding/2001/MC/x0011076\#!divAbstract

51. Kisil', S. P.; Burgart, Y. V.; Saloutin, V. I. Russ. J. Org. Chem. 2001, 37, 1455-1462.

http://dx.doi.org/10.1023/A:1013479323203

52. Lin, J.-P.; Long, Y.-Q. Chem. Commun. 2013, 49, 5313-5315.

http://dx.doi.org/10.1039/C3CC41690A

53. Ghosh, C. K.; Pal, C. Indian J. Chem. 1985, 24B, 1288-1290.

54. Costa, A. M. B. S. R. C. S.; Dean, F, M.; Jones, M. A.; Smith, D. A.; Varma, R. S. J. Chem. Soc., Chem. Commun. 1980, 1224-1226.

http://dx.doi.org/10.1039/C39800001224

55. Ciolkowski, M.; Malecka, M.; Modranka, R.; Budzisz, E. J. Mol. Struct. 2009, 937, 139145 .

http://dx.doi.org/10.1016/j.molstruc.2009.08.028

56. Suljic, S.; Mortzfeld, F. B.; Gunne, M.; Matthias, U.; Vlada, B.; Pietruszka, J. Chem. Cat. Chem. 2015, 7, 1380-1385.

http://dx.doi.org/10.1002/cctc.201500142

57. Wallace, T. W. Tetrahedron Lett. 1984, 25, 4299-4302.

http://dx.doi.org/10.1016/S0040-4039(01)81422-2

58. Saengchantara, S. T.; Wallace, T. W. Tetrahedron 1990, 46, 3029-3036.

http://dx.doi.org/10.1016/S0040-4020(01)88394-0

59. Crombie, B. S.; Redhouse, A. D.; Smith. C.; Wallace, T. W. J. Chem. Soc., Chem. Commun. 1995, 403-404.

http://dx.doi.org/10.1039/C39950000403

60. Crombie, B. S.; Smith. C.; Varnavas, C. Z.; Wallace, T. W. J. Chem. Soc., Perkin Trans 1 2001, 206-215.

http://dx.doi.org/10.1039/B005617K

61. Daia, D. E.; Gabbut, C. D.; Heron, B. M.; Hepworth, J. D.; Hursthouse, M. B.; Malik, K. M. A. Tetrahedron Lett. 2003, 44, 1461-1464. 


\section{http://dx.doi.org/10.1016/S0040-4039(02)02857-5}

62. Stubbing, L. A.; Freda, F.; Furkert, D. P.; Caprio, V. E.; Brimble, M. A. Tetrahedron 2012, 68, 6948-6956.

http://dx.doi.org/10.1016/j.tet.2012.05.115

63. Cremins, P. J.; Hayes, R.; Wallace, T. W. Tetrahedron 1991, 47, 9431-9438. http://dx.doi.org/10.1016/S0040-4020(01)80889-9

64. Cremins, P. J.; Hayes, R.; Wallace, T. W. Tetrahedron 1993, 49, 3211-3220. http://dx.doi.org/10.1016/S0040-4020(01)89903-8

65. Saloutin, V. I.; Skryabina, Z. E.; Bazyĺ, I. T.; Kisil', S. P. J. Fluorine Chem. 1999, 94, 8390.

http://dx.doi.org/10.1016/S0022-1139(98)00350-9

66. Budzisz, E.; Brezezinska, E.; Krajewska, U.; Rozalski, M. Eur. J. Med. Chem. 2003, 38, 597-603.

http://dx.doi.org/10.1016/S0223-5234(03)00086-2

67. Budzisz, E.; Keppler, B. K.; Giester, G.; Wozniczka, M.; Kufelnicki, A.; Nawrot, B. Eur. J. Inorg. Chem. 2004, 4412-4419.

http://dx.doi.org/10.1002/ejic.200400483

68. Budzisz, E.; Malecka, M.; Lorenz, I.-P.; Meyer, P.; Kwiecien, R. A.; Paneth, P.; Krajewska, U.; Rozalski, M. Inorg. Chem. 2006, 45, 9688-9695. http://dx.doi.org/10.1021/ic0605569

69. Malecka, M.; Grabowski, S. J.; Budzisz, E. Chem. Physics 2004, 197, 235-244. http://dx.doi.org/10.1016/j.chemphys.2003.10.029

70. Shcherbakov, K. V.; Burgart, Y. V.; Saloutin, V. I. Russ. Chem. Bull. 2005, 54, 2157-2162. http://dx.doi.org/10.1007/s11172-006-0091-8

71. Shcherbakov, K. V.; Burgart, Y. V.; Saloutin, V. I. Russ. J. Org. Chem. 2013, 49, 719-729. http://dx.doi.org/10.1134/S1070428013050151

72. Bazyĺ, I. T.; Kisil', S. P.; Frolov, S. N.; Burgart, Y. V.; Saloutin, V. I. Russ. Chem. Bull. 1999, 48, 1537-1541.

http://dx.doi.org/10.1007/BF02496408

73. Ghosh, C. K.; Pal, C.; Bhattacharyya, A. Indian J. Chem. 1985, 24B, 914-917.

74. Abdel-Aziz, S. A.-G.; El-Sayed Ali, T.; El-Mahdy, K. M.; Abdel-Karim, S. M. Eur. J. Chem. 2011, 2, 25-35.

http://dx.doi.org/10.5155/eurjchem.2.1.25-35.208

75. El-Sway, E. R.; Shaker, K. H.; Mandour, A. H.; El-Din, A. S.; Abdula, M. M. Indian J. Chem. 2008, 47B, 1451-1462.

http://nopr.niscair.res.in/bitstream/123456789/2009/1/IJCB\%2047(9)\%201451-1462.pdf

76. Jamode, V. S.; Kale, A. S. Asian J. Chem. 2006, 18, 3197-3200.

http://www.asianjournalofchemistry.co.in/user/journal/viewarticle.aspx?ArticleID=18 4 _ 1 $\underline{42}$

77. Chantegrel, B.; Nadi, A. I.; Gelin, S. Tetrahedron Lett. 1983, 24, 381-384. 


\section{http://dx.doi.org/10.1016/S0040-4039(00)81413-6}

78. Chantegrel, B.; Nadi, A. I.; Gelin, S. J. Org. Chem. 1984, 49, 4419-4424. http://dx.doi.org/10.1021/jo00197a018

79. Budzisz, E.; Malecka, M.; Nawrot, B. Tetrahedron 2004, 60, 1749-1759. http://dx.doi.org/10.1016/j.tet.2003.12.044

80. Malecka, M.; Massa, W.; Harms, K.; Budzisz, E. J. Mol. Struct. 2005, 737, 259-265. http://dx.doi.org/10.1016/j.molstruc.2004.10.111

81. Kufelnicki, A.; Woznicka, M.; Checinska, L.; Miernicka, M.; Budzisz, E. Polyhedron 2007, 26, 2589-2596.

http://dx.doi.org/10.1016/j.poly.2006.12.043

82. Miernicka, M.; Szulawska, A.; Czyz, M.; Lorenz, I.-P.; Mayer, P.; Karwowski, B.; Budzisz, E. J. Inorg. Biochem. 2008, 102, 157-165. http://dx.doi.org/10.1016/j.jinorgbio.2007.07.040

83. Quiroga, J.; Portilla, J.; Abonia, R.; Insuasty, B.; Nogueras, M.; Cobo, J. Tetrahedron Lett. 2008, 49, 6254-6256.

http://dx.doi.org/10.1016/j.tetlet.2008.08.044

84. Bazyĺ, I. T.; Kisil', S. P.; Burgart, Y. V.; Saloutin, V. I. J. Fluorine Chem. 2000, 103, 3-12. http://dx.doi.org/10.1016/S0022-1139(99)00210-9

85. Bazyĺ, I. T.; Kisil', S. P.; Burgart, Y. V.; Saloutin, V. I. Russ. J. Org. Chem. 2000, 6, 904909.

86. Li, Z.; Dellali, A.; Malik, J.; Motevalli, M.; Nix, R. M.; Olukoya, T.; Peng, Y.; Ye, H.; Gillin, W. P.; Hernández, I.; Wyatt, P. B. Inorg. Chem. 2013, 52, 1379-1387. http://dx.doi.org/10.1021/ic302063u

87. Kapoor, R. P.; Rastogi, M. K.; Khanna, R.; Garg, C. P. Indian J. Chem. 1984, 23B, 390392.

88. Garg, C. P.; Sharma, V. P.; Kapoor, R. Indian J. Chem. 1985, 24B, 1197-2000.

89. Garg, C. P.; Sharma, V. P.; Chhabra, V.; Kapoor, R. Indian J. Chem. 1988, 27B, 469-471.

90. Sharma, V. P. Asian J. Chem. 2005, 17, 887-894. http://www.asianjournalofchemistry.co.in/user/journal/viewarticle.aspx?ArticleID=17 23 $\underline{6}$

91. Javed, T.; Kahlon, S. S. J. Heterocycl. Chem. 2002, 39, 627-630. http://dx.doi.org/10.1002/jhet.5570390404

92. Ghosh, C. K.; Ghosh, C.; Karak, S. K.; Chakravarty, A. K. J. Chem. Res. 2004, 84-86. http://dx.doi.org/10.3184/030823404323000927

93. Ghosh, C. K.; Karak, S. K.; Chakravorty, A. K. Indian J. Chem. 2004, 43B, 2401-2404.

94. Krayushkin, M. M.; Levchenko, K. S.; Yarovenko, V. N.; Christoforova, L. V.; Barachevsky, V. A.; Puankov, Y. A.; Valova, T. M.; Kobeleva, O. I.; Lyssenko, K. New. J. Chem. 2009, 33, 2267-2277.

http://dx.doi.org/10.1039/B9NJ00237E

95. Charlton, J. L.; Sayeed, V. A.; Lypka, G. N. Can. J. Chem. 1982, 60, 1996-2001. 


\section{http://dx.doi.org/10.1139/v82-281}

96. Ghosh, C. K.; Bhattacharyya, S. Indian J. Chem. 1999, 38B, 166-172.

http://nopr.niscair.res.in/bitstream/123456789/16226/1/IJCB\%2038B\%282\%29\%20166172.pdf

97. Ghosh, C. K.; Sahana, S.; Patra, A. Tetrahedron 1993, 49, 4127-4134. http://dx.doi.org/10.1016/S0040-4020(01)89924-5

98. Gong, J.; Xie, F.; Ren, W.; Chen, H.; Hu, Y. Org. Biomol. Chem. 2012, 10, 486-489. http://dx.doi.org/10.1039/C1OB06613G

99. Ghosh, C. K.; Pal, C.; Maiti, J.; Sarkar, M. J. Chem. Soc., Perkin Trans. 1 1988, 14891493.

\section{http://dx.doi.org/10.1039/P19880001489}

100. Ghosh, C. K.; Pal, C.; Maiti, J.; Bhattacharyya, A. Indian J. Chem. 1989, 28B, 448-453.

101. Ghosh, C. K.; Bhattacharyya, S.; Ghosh, C.; Patra, A. J. Chem. Soc., Perkin Trans. 1 1999, 3005-3013.

http://dx.doi.org/10.1039/A903145F

102. Patel, M. N.; Pansuriya, P. B.; Chhasatia, M. R. Appl. Organomet. Chem. 2008, 22, 415426.

http://dx.doi.org/10.1002/aoc.1417

103. Pansuriya, P. B.; Patel, M. N. Appl. Organomet. Chem. 2007, 21, 926-934. http://dx.doi.org/ 10.1002/aoc.1321

104. Pansuriya, P. B.; Patel, M. N. Appl. Organomet. Chem. 2007, 21, 739-749. http://dx.doi.org/ 10.1002/aoc.1287

\section{Authors' Biographies}

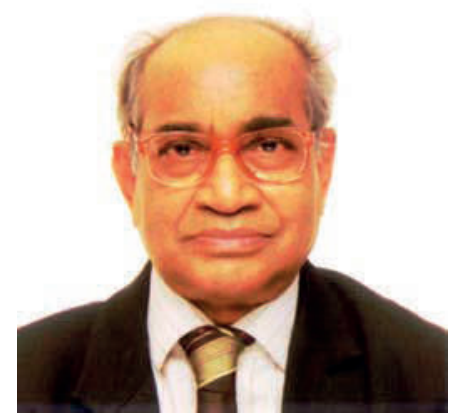

Chandra Kanta Ghosh got from the University of Calcutta his M.Sc., Ph.D. and D.Sc. degrees in Chemistry in 1965, 1970 and 1996, respectively. He did his postdoctoral research in the Department of Organic Chemistry, Karlsruhe University, Germany (1973-74) and in the Biology Division of Oak Ridge National Laboratory, USA (1979-80). He was a faculty member in Organic Chemistry Section in the Department of Biochemistry, Calcutta University during 19692007. Even after his formal retirement as a Professor in 2007, Dr. Ghosh has contributed to many journals. His research interests lies mainly in the chemistry of 1-benzopyran-4-one (chromone) 
having an electron withdrawing group at its 3-position. He has so far sixty six publications in this field.

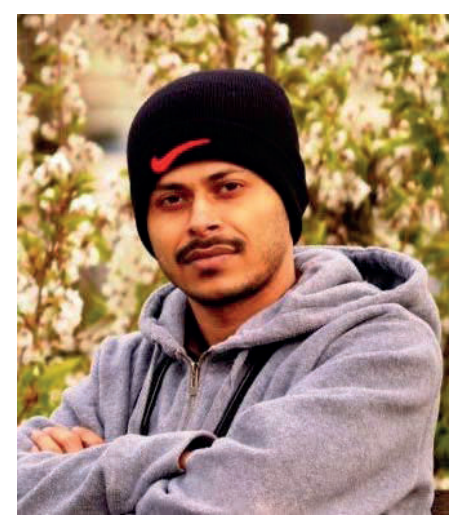

Amarnath Chakraborty received his B.Sc. and M.Sc. in Chemistry from Vidyasagar University, India in 2002 and 2004 respectively. After obtaining Ph.D. in 2011 for his work on organometallic chemistry with Professor Amitabha Sarkar in Indian Association for the Cultivation of Science (IACS), Kolkata, he moved to Radboud University, Netherlands for his postdoctoral research with Professor Jan C. M. van Hest. Then he joined the laboratory of Professor Amitabha Sarkar as a Research Associate in the Department of Organic Chemistry at IACS, Kolkata. Currently he is an Assistant Professor at the Department of Basic Sciences and Humanities in the Institute of Engineering \& Management (IEM), Salt Lake, Kolkata, India. His current research interest is focused on synthetic organic and organometallic chemistry as well as the synthesis of novel heterocycles from 1-benzopyran-4-ones. 